\title{
Offshore multi-purpose platforms for a Blue Growth: a technological, environmental and socio-economic review
}

Abhinav, K A ${ }^{\mathrm{a}}$, Collu, Maurizio ${ }^{\mathrm{a},{ }^{*}}$, Benjamins, Steven ${ }^{\mathrm{b}}$, Cai, Huiwen ${ }^{\mathrm{c}}$, Hughes, Adam ${ }^{\mathrm{b}}$, Jiang, Bo ${ }^{\mathrm{d}}$, Jude, Simon ${ }^{\text {h }}$, Leithead, William ${ }^{\mathrm{e}}$, Lin, Cui ${ }^{\mathrm{d}}$, Liu, Hongda ${ }^{\mathrm{f}}$, Recalde-Camacho, Luis ${ }^{\mathrm{e}}$, Serpetti, Natalia ${ }^{\mathrm{b}}$, Sun, $\mathrm{Ke}^{\mathrm{g}}$, Wilson, Ben ${ }^{\mathrm{b}}$, Yue, Hong ${ }^{\mathrm{e}}, \mathrm{Zhou}$ Bin-Zhen ${ }^{\mathrm{g}}$

${ }^{a}$ Naval Architecture, Marine and Ocean Engineering, University of Strathclyde, Glasgow, UK

${ }^{b}$ Scottish Association for Marine Science, Scottish Marine Institute, Oban, PA37 1QA, UK

${ }^{c}$ Zhejiang Ocean University, Changzhi Island, Zhoushan, Zhejiang, China

${ }^{d}$ National Ocean Technology Center, No. 219, West Jieyuan Road, Tianjin, China

${ }^{e}$ Electronic and Electrical Engineering, University of Strathclyde, Glasgow, UK

${ }^{f}$ College of Automation, Harbin Engineering University, Harbin, China, 150001

${ }^{g}$ College of Shipbuilding Engineering, Harbin Engineering University, Harbin, China, 150001

${ }^{h}$ Cranfield University, Bedford, UK

\begin{abstract} industries.

\footnotetext{
* Corresponding author

Email address: maurizio.collu@strath.ac.uk (Collu, Maurizio)
}

"Blue Growth" and "Blue Economy" is defined by the World Bank as: "the sustainable use of ocean resources for economic growth, improved livelihoods and jobs, while preserving the health of ocean ecosystem". Multi-purpose platforms (MPPs) can be defined as offshore platforms serving the needs of multiple offshore industries (energy and aquaculture), aim at exploiting the synergies and managing the tensions arising when closely co-locating systems from these

Despite a number of previous projects aimed at assessing, from a multidisciplinary point of view, the feasibility of multipurpose platforms, it is here shown that the state-of-the-art has focused mainly on single-purpose devices, and adopting a single discipline (either economic, or social, or technological, or environmental) approaches. Therefore, the aim of the present study is to provide a multidisciplinary state of the art review on, whenever possible, multi-purpose 
platforms, complementing it with single-purpose and/or single discipline literature reviews when not possible. Synoptic tables are provided, giving an overview of the multi-purpose platform concepts investigated, the numerical approaches adopted, and a comprehensive snapshot classifying the references discussed by industry (offshore renewables, aquaculture, both) and by aspect (technological, environmental, socio-economic). The majority of the multi-purpose platform concepts proposed are integrating only multiple offshore renewable energy devices (e.g. hybrid wind-wave), with only few integrating also aquaculture systems. MPPs have significant potential in economizing CAPEX and operational costs for the offshore energy and aquaculture industry by means of concerted spatial planning and sharing of infrastructure.

Graphical abstract

\section{Highlights}

- A number of projects on multipurpose platforms, aiming to conduct multidisciplinary feasibility assessments, have been done.

- Despite them, there is a lack of multidisciplinary analyses for multipurpose platforms.

- This work therefore aims at reviewing state-of-the-art multidisciplinary analyses on MPPs, complementing them with the review of single-purpose, single discipline analyses when necessary.

- A review of technological, environmental, and socio-economic analyses of ORE devices and aquaculture systems is given.

Keywords: Multi purpose platform, multi use platform, marine renewable energy, offshore wind, wave, aquaculture, social science

2010 MSC: 00-01, 99-00 


\section{Introduction}

\subsection{Context}

The marine environment represents a vast source of renewable energy. Energy is available in multiple forms - wind, wave, tides, currents, and temperature and pressure gradients. The successful commercial exploitation of these energy sources is perceived as a key target to be able to tackle the energy trilemma [1]: to provide secure, sustainable, and affordable energy. However, targeted installed capacities for 2050 (460 GW for offshore wind [2] and $188 \mathrm{GW}$ for tidal and wave [3]) can be achieved only by lowering the cost of the energy produced, possibly through the combined extraction of more than one marine resource. In this regard, offshore wind farms and aquaculture have been proposed as suitable candidates for co-location/multiple use, in the recent past $[4,5,6]$.

Of the various offshore renewable energy (ORE) systems, bottom fixed offshore wind turbines can be considered as commercially mature. On the other hand, floating offshore wind turbines (FOWTs) have been slowly evolving from concepts to reality [7], in recent decades. This upswing in the demand for FOWTs has been brought about by a combination of several factors stronger and less turbulent offshore winds, reduced visual pollution and mulit-use conflicts, for instance. However, other offshore renewable energy (ORE) systems, such as wave energy converters, still need to be further developed, in order to be considered commercially competitive.

In parallel with the energy trilemma, the Food and Agriculture Organization (FAO) estimates that, by 2030 , the demand for seafood will exceed the supply by 40 million metric tonnes [8]. With constraints limiting the possibilities for the expansion of inland and near-shore fisheries, offshore aquaculture has emerged as a viable alternative for increasing the global seafood production. Aquaculture is classified as offshore, if it takes place in the open sea, exposed to significant met-ocean conditions [9]. Notwithstanding the challenges posed by the open ocean, offshore farming offers several advantages - increased possibilities for expansion, reduced exposure to pollution from human sources and the potential of co-locating infrastructure with ORE systems to reduce competition for operational space [10].

Thus, a proposed solution for a reliable energy extraction and aquaculture development, while addressing the questions of CAPEX, space limitation and operational safety could be the use of Multi-Purpose Platforms (MPPs). Ideally, an MPP is an offshore structure able to exploit the synergies between ORE systems and aquaculture systems, avoiding by design the conflicts arising 
from the close co-location of these systems. MPPs are expected to bring about significant cost reduction, by allowing multiple use of space and infrastructure, through co-located and shared technologies [11, 12]. MPPs would also promote an optimization of the marine spatial planning,

proposing an efficient, integrated, sustainable, and ecological use of oceanic resources through shared spaces and infrastructure [12, 13, 14].

Furthermore, for remote and island communities, not able to access the utilities grids, an MPP may constitute the only secure, sustainable, and affordable source of energy [15, 16], food, and jobs.

\subsection{Aim, objectives, and structure of the review}

Despite a number of EU-funded projects aimed at assessing the feasibility of multipurpose platforms, also highlighting the importance of a multidisciplinary approach, it is here shown that the analyses available in the literature are (expect for very few cases) mainly focused on single-purpose devices, or at best hybrid wind-wave offshore renewable energy devices, and tackling the challenge only from a single discipline (either technological and/or economic, or social and/or economic, or environmental) point of view.

Therefore, the aim of the present study is to provide a state of the art review on, multidisciplinary technological, economic, and socio-environmental reviews on offshore multi-purpose platforms. This is to provide the ideal basement for a truly multi-purpose, multi-discipline analysis framework, for current and future projects looking at MPP systems. The scope of this review is limited to the most developed ORE resources - wind and wave.

While the terms MPP and multi-use of ocean space (MUS) are often used interchangeably, the distinction between the two has to be clearly understood. While MPP refers to a structure capable of exploiting the synergies between different ORE systems or aquaculture, MUS has a more general definition - 'the joint use of resources in close geographic proximity by either a single user or multiple users' [17] i.e., not necessarily a single platform.

\subsection{Overview of previous projects}

Combining different ORE systems onto the same platform structure offers several benefits: increased, more consistent power production, thanks to the different patterns of different renewable energy sources, lower CAPEX-to-rated power ratio, shared balance-of-plant operations 
and maintenance $(\mathrm{O} \& \mathrm{M})$ costs, positive dynamics interactions (e.g. wave energy converters (WECs) as additional damping systems for the OWT with which are coupled, ensuring a lower response to waves), are some of the main technological advantages. Pérez-Collazo et al. [18] have also identified potential project and legislative synergies. During the past decade, several European projects have investigated the technical challenges of combined ORE extraction systems. The design concepts defined by these projects are explained in detail, in the following paragraphs.

The MARINA platform project [19] identified three designs of OWT-WEC combinations for further study - the spar torus combination (STC), the semi-submersible flap combination (SFC), and the 'OWC' array with a wind turbine. In the STC [19], the NREL 5 -MW OWT [20] is supported on a spar, and the torus (an axisymmetric point absorber that operates mainly in heave) extracts wave energy by moving along the spar, by means of a hydraulic power take-off (PTO) system. The SFC [21] comprises a semi-submersible floater with four columns (one at the centre and three at the sides) connected by means of pontoons. The central column supports the turbine and rotating flaps hinged at the pontoons capture the wave energy, making use of a hydraulic PTO system to generate electricity. The OWC array consists of a large floater having multiple WECs and supporting a single wind turbine [22].

The ORECCA project [23] classified combined platforms into offshore hybrids and energy islands. The former refers to a combination of wind and wave (or tide) energy devices, while the latter denotes large multi-purpose platforms capable of utilizing multiple sources of ocean energy, possibly in combination with an offshore harbour [24].

A modular approach for multi-purpose platforms, combining the attributes of transport, energy, aquaculture and leisure (TEAL) was proposed by the TROPOS project [25]. Different TEAL modules can be accommodated around a central unit to cater to the local socio-economic and environmental conditions, thus affording flexibility to the concept.

The H2OCEAN [26] project proposed multi-purpose platforms aimed at the production of hydrogen, perceived as the future energy vector. A farm of hybrid floating wind-wave energy devices, coupling a 5MW H-type vertical axis wind turbine (VAWT) with a WEC, provides electricity to a central platform, where the energy is transformed into hydrogen, and to an aquaculture system.

The MERMAID project [27] explored the possibility of using innovative multi-purpose 
platforms for combining food (aquaculture) and energy production, on the basis of site-specific environmental challenges.

The W2Power concept supports two WT's on a triangular platform, with WEC's attached in arrays along the 3 sides [28]. Each platform has been envisaged to reach a rated power around 10 MW. The WindWaveFloat intends to equip the WindFloat (a semi-submersible type FOWT structure with three columns) with different types of WECS, such as OWC's and point absorbers [29]. The addition of the WEC's were observed to have minimal influence on the motion of the support structure.

The Poseidon, developed by Floating Power Plant A/S, is a semi-submersible platform for combined wind-wave energy extraction, which can support 10 floating wave energy absorbers ( $3 \mathrm{~kW}$ ) and 3 wind turbines (11 kW) [30]. The Wave Dragon, a multi-MW overtopping WEC, has been a pioneer in the field of wave energy generation [31]. The Wave Dragon is also capable of supporting two 2.3 MW wind turbines, with significant savings in the levelized cost of energy (LCoE) [32].

\subsubsection{MPP: comparison of functionality}

The functionality of the MPP concepts discussed above are compared in Table 1. It is noticeable how the majority of the platforms are hybrid wind-wave energy devices, with only a few including aquaculture systems. Furthermore, it may be noted that majority of the concepts are publicly funded and subsidized, thus highlighting the novelty of the platforms. Also, the rated power varies from $10^{2}$ to $10^{4} \mathrm{~W}$, reflecting the potential variety of applications and markets of the MPP concepts.

Table 1: MPP concepts - Comparison of functionality

\begin{tabular}{|c|l|c|c|c|c|}
\hline No. & Platform & Wind & Wave & Aquaculture & Solar \\
\hline 1 & Sea Star Spar [33] & $\checkmark$ & & $\checkmark$ & \\
\hline 2 & STC [19] & $\checkmark$ & $\checkmark$ & & \\
\hline 3 & W2Power [28] & $\checkmark$ & $\checkmark$ & & \\
\hline 4 & SFC [21] & $\checkmark$ & $\checkmark$ & & \\
\hline 5 & OWC Array [22] & $\checkmark$ & $\checkmark$ & & \\
\hline
\end{tabular}




\begin{tabular}{|c|l|c|c|c|c|}
\hline 6 & Poseidon [30] & $\checkmark$ & $\checkmark$ & & \\
\hline 7 & TROPOS [34] & $\checkmark$ & & $\checkmark$ & $\checkmark$ \\
\hline 8 & MERMAID [35] & $\checkmark$ & $\checkmark$ & & \\
\hline 9 & WT - feed barge[36] & $\checkmark$ & & $\checkmark$ & \\
\hline 10 & Ocean Farm1 [37] & & & $\checkmark$ & \\
\hline 11 & Wave Dragon [31] & $\checkmark$ & $\checkmark$ & & \\
\hline
\end{tabular}

Over 200 scientific articles have been accessed as part of the present review paper, with most of them $(\sim 70 \%)$ published during or after 2010 . The methodology to organise this multidisciplinary review has been the following the selected papers were initially classified on the basis of the discipline they represent - technological (section 2), environmental (section 3) and socioeconomic (section 4). Further, the literature reviewed in each section has been subdivided with respect to the resource they exploit - ORE (wind, wave or combined) or aquaculture. As overarching topic, including aspects from different disciplines, the studies related to MPPs and risk are reviewed in section 5. An overview and discussion of the literature reviewed is presented in section 6, with conclusions provided in section 7.

\section{Technological aspects}

\subsection{ORE}

The following subsections discuss the technological aspects of combined ORE systems, where the outcomes of the previous projects have been highlighted. While most concepts from these projects have been subjected to numerical modelling studies, a few of them have reached the stage of experimental testing as well. The approaches followed in numerical modelling and experimental testing have been mentioned in detail. Aquaculture systems (both standalone and integrated with ORE devices) have also been discussed. A review of the control aspects of MPPs is also presented in this section.

\subsubsection{Model of dynamics: numerical and experimental methods}

Several MPP systems described in Section 2.1 have been subjected to numerical modelling. The SFC and the STC have been numerically analyzed in the time domain [38, 39], by 
coupling the SIMO [40] and RIFLEX [41] software. SIMO is used to compute the hydrodynamic loads on rigid floating bodies. RIFLEX is a nonlinear program for modelling wave loads on slender structures, like mooring lines using the Morison equation, and aerodynamic loads on wind turbine blades using blade element momentum (BEM) theory. The models were a combination of flexible and rigid bodies, and potential theory was used to estimate the wave loads. The same approach was adopted to model the WindWEC [42], a hybrid combination of the Hywind SPAR [43] and the Wavestar [44] WEC buoy.

Soulard et al. [45] used a wave to wire representation based on linear potential theory to model the fluid-structure interaction of a $100 \mathrm{~m}$ diameter circular hybrid platform (C-HyP), supporting the NREL 5-MW OWT, and an array of oscillating WECs. Aerodynamic loads were imposed at the nacelle, through a simplified procedure [46] which makes use of the relative wind speed with respect to the platform motion. The motion of a multi-use platform (MUP) developed for the MERMAID project [47] was studied in the time domain, using the open source boundary element method solver, NEMOH [48]. A coupled system of 21 DOF's were used to model the interactions between the platform, WECs and the air pressure inside the chambers. Quasi-static approaches were used to represent the influence of the wind loads on the turbine.

Li et al. [49] proposed the Hywind-Wavebob-NACA 638xx Combination (HWNC) by integrating the Hywind SPAR [43] OWT with the Wavebob point absorbers [19] and tidal turbines [50]. Hydrodynamic and aerodynamic considerations were included by means of linear potential flow and blade element momentum theories, respectively. A multi-body dynamics approach was adopted for simulating mechanical connections and the mooring lines were represented using a lumped-mass approach.

Table 2: Comparison of numerical models for MPPs

\begin{tabular}{|c|l|c|c|c|}
\hline No. & Platform & Aerodynamics & Hydrodynamics & Structural dyn. \\
\hline 1 & SFC [38] & BEM & potential flow & multibody \\
\hline 2 & STC [39] & wind drag force & potential flow & multibody \\
\hline 3 & WindWEC [42] & BEM & potential flow & rigid body/FEM \\
\hline 4 & C-HyP [45] & relative wind speed & potential flow & lumped mass \\
\hline 5 & MERMAID [47] & relative wind speed & potential flow & rigid body \\
\hline 6 & HWNC [49] & BEM & potential flow & multibody \\
\hline
\end{tabular}


A summary of the numerical modelling approaches discussed is presented in Table 2. It can be observed that a variety of approaches have been adopted for representing the aerodynamics aspects, ranging from a simple static wind drag force (generated by a body that opposes the flow of wind), to the more accurate blade element momentum (BEM) theory (where the blades are divided into elements and the forces acting on them are summed up together). As far as the hydrodynamics is concerned, all the models adopt a wave diffraction based potential flow approach, which is ideal for large structures. The structural dynamics aspects are modelled with different approaches and level of fidelity/accuracy. In a rigid body approach, the whole body is considered rigid and therefore there is no elastic deformation, while in a multibody approach, the system is comprised of several bodies linked by joints that control their relative motion.

The SFC and the STC mentioned above have been tested experimentally, at a scale of 1:50. The SFC consists of a semisubmersible floating wind turbine and three fully submerged rotating flap-type WECs. The PTO configuration of each of the WECs were physically modelled with the use of a shaft, two pulleys, a timing belt, two tensioners and a linear mechanical rotary damper with constant damping level during the execution of the tests [39]. The wind turbine was modelled with a redesigned small-scale rotor that rotates during the experiments. The quasi-static excitation, motion decay, response under regular and irregular waves, without and with wind were tested for and a good agreement was observed with numerical predictions.

The STC model was tested in two different basins to account for experimental uncertainties. Two model tests were performed to investigate the performance of the STC under the two survival modes in extreme conditions: when the torus is fixed to the spar at the mean water level and when the torus is fixed to the spar at a submerged position. The focus of the model tests was wave-induced loads and responses, and wind was also included to model the mean wind thrust on the wind turbine rotor $[51,38,52]$.

The above mentioned previous European projects investigated the performance of platforms suitable for large wind farms of the order of 0.5 to $1 \mathrm{GW}$. There, however, arises a need to study the response of small MPP's capable of catering to the power requirements of remote and island communities, which might be substantially different from those already investigated. 


\subsection{Aquaculture}

Aquaculture refers to the cultivation of fish and other aquatic organisms in a controlled manner, for human consumption. Marine aquaculture systems employ a variety of designs, based on the type of seafood harvested. They can be moored to the seabed, tied to a structure or towed by vessels [53]. Cage type structures anchored to the sea floor are generally preferred for finfish [54]. Shellfish cultivation is done either by bottom farming or by making use of lines suspended beneath floating bodies like buoys, rafts and longlines.

Aquaculture in more exposed, harsher conditions is perceived to be the next step, with a number of projects looking at suitable concepts, and a full scale pilot test facility represented by SalMar's "Ocean Farm1" [37], already in operation. The Ocean Farm 1 is a semi-submersible rigid cage of $110 \mathrm{~m}$ diameter, capable of housing up to 1.5 million salmon. Vessel type rigid floating cages or Havfarms [55], capable of withstanding $10 \mathrm{~m}$ significant wave heights are also being planned for use in the near future.

\subsection{Combined ORE and Aquaculture}

The Sea Star Spar [33] proposed a combination of a spar floating wind turbine and floating structures with sufficient buoyancy for the cultivation of finfish, shellfish or algae. Goseberg et al. [56] investigated the interaction between OWT structures and aquaculture systems by experimentally analysing the scaled model of a tripile supporting a 5 MW turbine, with a fish cage installed between its legs. Variations in flow velocities and additional loads on the substructure, arising from the presence of the cages were detected. Under the MARIBE project [57], different combinations of offshore wind, wave and aquaculture systems were identified, considering multi-use of space (MUS) and MPP criteria.

Viúdez et al. [58] proposed the use of a spar-type OWT to create an artificial upwelling of the nutrient-laden waters from the deep to increase the surface fish production. An experimental study on wave energy systems at Lysekil on the Swedish coast concluded that structural modification of the foundations (perforations, in this case) and other components could lead to enhancements in the fish population [59].

\subsubsection{Control Strategies}

Control systems form an integral part of any energy system. Coupling several ORE 
technologies and energy storage on a single MPP for aquaculture operations calls for a hybrid control system. This is due to the fact that while aquaculture requires a smooth, stable supply of power, ORE systems are highly dependent on their environmental source for power production. This can often result in periods of zero power production [60]. The existing scenario in control strategies for MPPs is reviewed in the following subsections.

\subsubsection{Challenges of MPP control system}

For an MPP combining ORE and aquaculture, while the latter can smooth the influence of waves and currents on the platform [61], it also has an impact on the layout of the power generation equipment [62]. Also, the interaction between the floating platform, wind turbine, WECs and energy storage (ES) devices, exists in many aspects such as the motion response, the dynamic loads and the control system, making the MPP a highly complex and coupled system.

The power supply of the MPP should be smooth and stable to meet the requirements of both the platform operations and the aquaculture system. The power transmission between land substation and the MPP also needs to be stable. As a result, power generation, ES and electrical equipment on the MPP need an overall power control and capacity management system. No comprehensive review of control technologies for MPPs currently exists. However, reviews on control of wind and wave devices [63], and control of energy storage (ES) systems [64], are useful for the present purpose.

Control systems for each ORE technology aims to operate the devices at their rated values by following an operating strategy, whilst maintaining safe operating conditions. The power generated by each technology depends on the renewable source cycle, leading to periods of zero power production. In an MPP, the combination of wind, wave and ES technologies can minimize the time of zero power production if shared control objectives are attained by means of a platform-level controller. These objectives can be classified as maximization of energy capture (wind and wave), regulation of generated power (wind, wave, ES), mitigation of structural loads for MPPs with large power capacity (wind, wave, platform), and reduction of unwanted platform swings and motions. For some types of ORE, estimation of the input can be of further benefit to the attainment of the control objectives, especially incident wave estimation for WECs [63].

The size of the MPP thus plays an important role in the definition of the control objectives. Promising wind/wave hybrid concepts estimate that the total installed capacity of around 10 - 
20 MW would include $20-25 \%$ of wave energy, since energy efficiency of the WEC is much less than that of the wind turbine [65].

\subsubsection{Management of power network and ES system}

The control of the electrical system is often treated separately from the control of the mechanical systems. The MPP grid is different from a conventional grid as the former depends basically on a collection of inverters and synchronous and/or asynchronous generators. Each generator will have a control system to provide voltage and frequency regulation. A power network management strategy is therefore required to provide the operating states to the local electrical control systems and also to control power sharing and achieve network stabilization. The power network management is developed based on the MPP size and type of interconnection (i.e., grid connected or isolated) [66]. Network stabilization and reactive power compensation can be further improved by the use of FACTS (flexible AC transmission systems) devices [67].

A detailed local electrical network (i.e., including loads, cabling network, protection, switchgear, transformers and a power network management, operation and control system) definition/identification is still required; as its optimal sizing to meet load requirements with minimum investment and operating costs [68]. Conventional methods for resynchronizing the local network to the main grid and power flow control between the two grids can be used [69].

An ES device can be used to suppress fluctuations of ORE [70]. Cao et al. [71] proposed a battery energy management system (BEMS) strategy, and the point estimate method is used to solve the volatility of ORE generation. Osório et al. [72] studied battery pack modelling and health feature extraction methods for an ocean power station to reduce the number of battery charging and discharging cycles and dump load, and to improve the life of ES devices. Methods of multi-scale energy management have been proposed based on power generation/load forecasting, in which the multi-time scale energy management model is combined with daily scheduling [70] and real-time scheduling [73]. Further, physical constraints also need to be addressed for ES system.

\subsubsection{Island/sea power integration}

The integration of island/sea area ORE power is mainly based on micro-grid technology including AC, DC and AC-DC hybrid micro-grids. The DC micro-grid avoids many problems such as the 
loop-current between multi-inverter, protection strategies of AC grids, which conforms better to systems with source diversity and load diversity $[74,75]$. According to the availability of grid support, micro-grid can be divided into the grid-connected island power supply system and the remote isolated power supply system. With the remote isolated power supply, several demonstration projects have been completed and put into operation, such as the Dongfushan and Nanji islands in China [76, 77].

\subsubsection{Island/marine micro-grid control and management}

The micro-grid control system can be designed with different structures, i.e. the centralized control, the decentralized control and the hierarchical control. In the land-based and shore-based micro-grid demonstration projects, the centralized control is used more in Asia and the decentralized control mainly in Europe. The hierarchical model combines advantages of centralized and decentralized control, allowing better flexibility and scalability [78]. For the MPP control system, the use of hierarchical model is likely to be a better choice [79]. One recent successful example is the three-tier hierarchical management model applied in the marine micro-gird of China's Zhai Ruo mountain [80].

Grid planning has evolved from the realization of the grid-connected/off-grid function and the smooth transition process in early time (through classical control and various intelligent control theories) to the economical, reliable, high-quality, environmentally power supply. The planning and design of the island micro grid can be realized from single-objective optimization to multi-objective optimization. Life cycle cost, power supply reliability, power supply quality and other indicators have been considered in the optimization [76, 81, 82, 83].

\section{Environmental Aspects}

\subsection{Environmental Impact Assessment}

\subsubsection{ORE}

Boehlert and Gill [84] have highlighted the major ecological and environmental concerns accompanying the development of various ORE systems. The different forms of ORE extraction were considered in isolation and impacts were studied on the basis of a stressor-receptor framework. Here, the former refers to environmental features susceptible to change from ORE development and the latter stands for elements of the ecosystem that may respond to the stressor. 
Among the potential hazards were habitat loss, bird hits (from moving turbine components), acoustic and electromagnetic emissions. Best practice measures for the mitigation of the effect of WTs on birds have also been mentioned [85]. Some WTs were recently dismantled in China due to the severe impact on the bird migration [86], indicating the importance of site selection assessment for the construction of wind farms.

Several environmental impact assessment studies have been carried out on individual wind and wave energy concepts. The main concern for acoustically-sensitive species such as marine mammals to date has been the construction phase of bottom fixed OWTs due to the widespread use of pile driving, with comparatively limited focus on sounds emitted by operational OWTs, let alone floating ones $[87,88,89,90]$. Nonetheless, the ability of species such as harbour seals and porpoises to detect and react to the sound emitted by operational OWTs has been identified as a potential concern [91]. Marine fish and invertebrates may be similarly hampered in terms of communication masking and disturbance $[92,93]$, although there is presently no evidence of noise emitted by operational OWTs causing physiological damage in fish [94]. Offshore WECs might present a collision risk for diving species and can potentially change local oceanographic processes by extracting large amounts of incident wave energy [95].

In addition to the adverse impacts, the potential benefits of ORE systems to biodiversity have also been suggested [96]. These include the potential for ORE structures to act as secondary artificial reefs to aid in the enhancement of fisheries and rehabilitation of marine habitats [97, 98, 99]. Floating ORE installations also have the capacity to act as local fish aggregation devices [97, 100]. As fishing around ORE installations is often prohibited, such areas can serve as miniature impromptu Marine Protected Areas (MPAs) [101]. Potential effects on wild species, as well as associated commercial/recreational fisheries, of this inadvertent protection presently remain poorly understood.

\subsubsection{Aquaculture}

At-sea aquaculture, particularly those involving finfish, can have multiple impacts on the surrounding marine environment (summarized by Tett et al. [102] focusing on Atlantic salmon). These include, in no particular order:

- impacts on wild fish stocks through increased parasite and pathogen densities [103, 104, $105,106]$, competition between wild and escaped fish for resources [107, 108, 109], and 
genetic dilution of local wild fish stocks through interbreeding with escaped fish (an acute problem for salmonids $[110,111])$

- degradation of surrounding seafloor communities through deposition of organic waste $[112,113]$, reduction in dissolved oxygen [114], eutrophication [115, 116, 117] and dispersal of various chemicals [118, 119]

- direct and indirect impacts on large mobile species such as marine mammals and seabirds, including shooting and exposure to loud underwater noises (to prevent depredation of cultured fish [120, 121]), accidental entanglement in nets and moorings [122], and displacement from potentially important habitats due to fish farm-associated activities $[123,124]$

Some positive impacts on particular species include provision of food and shelter for wild fish, and foraging and resting opportunities for marine mammals and seabirds (although this increases the risk of further negative interactions outlined above). Some of these impacts are indirectly driven by the inshore, sheltered nature of the sites where finfish aquaculture has developed to date. There is pressure to expand the sector into more exposed, offshore locations, which may reduce or modify some of the aforementioned impacts (e.g. eutrophication, attraction of wild fish) due to greater exposure and stronger water movements; however, the nature of these changes, if any, remains poorly understood and difficult to predict at present [125].

As for the considerable amount of biogenic waste such as organic wastes and inorganic nutrients that are generated in the fish farming process, trash fish (small fish of low commercial value) feeding showed more severe cumulative impact to the aquatic and sediment environment than pellet feed [126, 127, 128]. Trash fish is still a popular traditional feed for marine carnivorous fish in China and many Asian countries, and this practice is likely to persist for some time despite farmers are encouraged to use pelleted feed to minimize the environmental impact. Field monitoring, lab tank experiment and bioenergetics models were both applied to quantify the wastes generations and the environmental impact [128, 129, 130, 131, 132].

\subsubsection{Combined ORE and Aquaculture}

While ORE and aquaculture have matured as separate industries, the environmental impacts when these sectors are combined within a single site are very poorly understood and almost entirely based on theoretical projection of the single industry impacts on to a multi-use site. 
Much of this understanding has come from the European funded projects mentioned in section 1.3 and through application of cumulative effects assessment methods [133, 134].

The TROPOS project made use of an impact assessment approach to study the effects of combining the two industries, as opposed to a single use scenario [135]. To allow a direct comparison, a semi-quantitative scale was used for each impact category. This methodology used the difference between the impacts of a single use platform compared to those of a multi-use platform, and combined the impacts either on a an additive value of through the use of which ever value was highest, and this was conducted for both negative or positive attributes. It was concluded that while the impacts are similar for the single and multi-use approaches, the latter had the advantage of integrating diverse activities in a common location.

The H2OCEAN project was recognized that the impacts of different sectors may combine, and that the cumulative effects may reach thresholds of impacts, therefore recommending a comprehensive cumulative impact assessment [136]. Understanding of the impacts from multiple sectors of the system was limited to recommendations on the location of the living quarters, and their outfalls, to prevent potential conflicts [137].

Within the framework of an expert opinion approach, the MERMAID project identified a number of scenarios involving different combinations of aquaculture and ORE systems. Common environmental benefits, such as structures providing a refuge for wild fisheries species and operational constraints like increased bio-fouling, were also listed. A framework for risk analysis was also defined, including internal environmental interactions between the biota and different types of foundation and material [61].

\subsection{Ecological Modelling}

Modelling the effect of the installation of an MPP system in a marine ecosystem is challenging. On a large spatial scale, deployment of offshore structures for ORE generation will lead to exclusion zones, limiting the access to the area for several users such as shipping, fishing and tourism $[138,139,140,141]$. Such infrastructure can also underpin development of 'artificial reefs', supplying nursery areas and feeding grounds for fish species [142, 97]. Species larvae and juveniles can disperse to the surrounding areas leading to a 'spill-over effect', enhancing local production [143, 144, 145]. These infrastructures can also create new substrates for benthic organisms $[146,99,147]$. The creation of new benthic habitats can lead to either displacement or 
attraction of benthic species in the local area, resulting in changes to local food-web dynamics with both positive and negative impacts on species distribution and abundances [148, 149, 150,151].

Aquaculture associated with the MPP structure can increase the productivity in the water column and on the surrounding sediment (detritus enrichment): depending on the characteristics of the surrounding environment, this increased productivity can lead to large-scale impact, attracting top-predators species [152], and small-scale impact, affecting benthic faunal communities, important food source for many species including those of commercial importance [83].

'Exclusion zones effect' and 'artificial reef effect' can therefore lead to both synergies and conflicts with other marine users, notably the fishing industry [153, 154, 155]. Modelling small-scale impacts will require a high resolution of the model spatial grid with associated high computing power [141, 83].

Ecosystem-based approaches are necessary to investigate the cumulative effects of human impacts on marine ecosystems [156, 157, 158, 159, 160, 161, 144, 162, 145, 163]. Ecosystem models have proved to be a powerful tool for monitoring natural variability, assessing impacts of natural and anthropogenic environmental changes and advising management measures $[164,165$, $161,166]$.

The Ecopath with Ecosim and Ecospace (EwE) modelling approach has been considered one of the most suitable tools for evaluating the direct and indirect effects of anthropogenic pressures on large spatial scale ecosystem dynamics [167, 168, 161, 169]. EwE models have been successfully used to evaluate how these pressures cascade through the food-web. For example, changing in the spatial distribution of top predators (cetaceans, large fish and seabirds) will affect the entire marine ecosystem through top-down control pathways [170,152]. Similarly, changing of primary productivity can cascade through the food-web by means of bottom-up controls [144, 145] as well as environmental drivers [144, 171]. The use of Ecospace to assess cumulative impacts of these effects have been exponentially increased since the later development of this software [172, 169, 144, 173], with new capabilities of coupling the spatial model with external spatial data (e.g. spatial habitats and hydrodynamic drivers). The EwE model has also been applied in the Bohai Sea, the Yellow Sea and the East China Sea to describe the energy transformation between trophic levels [174], to demonstrate the fishery resources declining due to overfishing [175] and the predominant fish species variation in the past decades [176, 177, 178]. 


\section{Socio-economic aspects}

Socio-economic is a term that defines the effect of a project - its development, operation and decommissioning, on the local population, or the society. There have been numerous studies on the socio-economic impacts of ORE and aquaculture, mostly undertaken on the basis of stakeholder interviews and surveys. The main inferences are listed below.

\subsection{ORE}

\subsubsection{Offshore wind}

Despite the advantages that offshore wind offers, several socio-economic drawbacks have been identified. A particularly problematic factor hampering the development of onshore wind farms, is public opposition arising from social concerns, such as visual pollution and the impact of noise [179].

Even as offshore wind farms are considered to be less intrusive than those onshore [180], public perception of the visual impact, notably shadow flicker and the impact on seascapes, remains an important concern [181].

In addition, whilst the underwater noise caused by the operation of wind farms has recently been shown to be of very low level and probably insufficient to cause any significant environmental effects [182], the noise which is created by the impact piling required for the foundation installation of OWTs has been found to be of extremely high level [183, 184, 89]. Such issues represent a challenge for the industry, planners and regulators as they can influence public opinion, which studies have observed to be dependent on demographics [185], with for instance, older people being more concerned with visual pollution [186].

Opposition also arises from concern over the fate of the local fishery industry [187, 188]. On the other hand, support for OWT projects arise from the understanding that they provide a non-polluting energy source, capable of generating jobs and contributing to the economy [189, 190].

\subsubsection{Wave energy}

The emergent nature of WECs, and the lack of commercial-scale deployments, results in uncertainties surrounding their potential positive and negative socio-economic effects and impacts. However, studies have highlighted a range of socio-economic impacts associated with 
WEC developments typically including demography, employment and regional income; sea and land use; aesthetics; infrastructure; socio-cultural systems and implications for other maritime activities such as fisheries, tourism and recreation [191, 192, 193, 194].

In addition to the benefit of providing a new source of electricity from a local, low carbon energy source, WEC developments will potentially bring economic benefits including the creation of jobs, the development of new supply chains and investment in infrastructure required to support such developments [194, 195]. However, uncertainties regarding the delivery of such benefits, and the potential displacement of jobs in different sectors have been identified as concerns [194]. Notably, WECs, like any other marine development activity, inevitably cause a change in the use of the ocean space at the deployment site that is likely to disrupt or displace the activities of other users of the area. Of increasing concern are potential restrictions on the accessibility and use of the surrounding marine space, introducing the risk of conflicts with other marine resource users and stakeholders [194, 196, 197, 198].

As with environmental concerns, the socio-economic effects and impacts of WEC will vary with the stage (construction, operation and decommissioning) and scale of the project and will depend on the location, communities, economy and environment in that area. For example, concerns regarding the ability of communities to adapt to changing demand for new services, skills throughout the WEC project lifecycle are emerging [194]. Furthermore, whilst some studies have argued that unlike wind energy, WEC developments do not cause visual pollution, as they are often located at great distances from the coasts and have mostly submerged configurations, this may not be true with differing WEC designs, deployment sites and community perceptions of the marine environment [199].

A further concern is that WECs may also provide non-market benefits, such as providing coastal protection benefits, they may negatively impact upon the ecosystems services and provisioning services, such as fisheries and the cultural services provided by the marine and coastal environment [194, 200]. Such issues are of particular concern because WEC developments are proposed in rural coastal locations and islands, where strong cultural ties to the marine and coastal environment exist and may result in community opposition [194].

Indeed, emergent research investigating such issues has identified divergent views on the socio-economic benefits and appropriateness of wave energy development [194]. For example, studies have attributed public support to wave energy being perceived as a renewable source and 
its capability to boost the local economy, without affecting established activities like fishing [201, 191]. Elsewhere, perceptions and support for WEC and ORE have been associated with place attachment, community pride and the 'symbolic fit' of place and technology [194, 202]. For example, Alexander et al. [141, 203] found broad support for WEC amongst Scottish fishers. However, the nascent nature of WEC technologies and deployment means that many are yet to form their views and opinions [191].

With community buy-in and support being vital to WEC deployment, there is clearly a need to maximize community benefits [194]. For example, some communities have questioned the potential benefits of WEC developments, which may result in increased electricity prices or taxes if subsidized. Thus, calls for wealth distribution and community benefit schemes, similar to those associated with other industries, have been made [194, 204]. These may range from community payments, to new forms of business models, including shared or community owned schemes [194]. The embryonic nature of WECs and the lack of commercial deployments also mean that there is a paucity of empirical research investigating their real world socio-economic impacts.

\subsection{Aquaculture}

Based on the available literature, Krause and Mikkelsen [205] have attempted to capture the socio-economic aspects of aquaculture, in a multi-use perspective. Socio-economic analysis have always taken the back seat, with regard to the development of aquaculture activities, the focus being on technical and biological issues [206]. Further, exiting studies concentrated on the influence of salmon, shrimp and seaweed farming [207]. Socio-economic studies for aquaculture have to be tailored to suit the local economic and geo-political settings and the outcomes cannot be generalized. For instance, in a study on risk perception and management in Norwegian aquaculture, fish farmers were more concerned about the future prices of their stock and potential disease outbreaks. On the other hand, they were least bothered about aesthetic considerations and repugnance to the public [208].

While food and jobs are the main direct socio-economic benefits from aquaculture, it has to be noted that in many Asian countries like Vietnam and Bangladesh [209, 210], the fishermen community is struggling to survive with the generated income. Further, the negative effects of aquaculture have been difficult to quantify, mainly due to the lack of knowledge and awareness among the consumers [211]. The recent decades have witnessed large degradation of the coastal 
marine environment and its resources in many areas, at least partly due to an unprecedented growth of the aquaculture industry, coupled with the absence of proper national and international regulations, policies and management strategies [212, 213].

There are several studies on the sustainable development of offshore aquaculture, wherein the society, economics and environment are given due consideration [214, 215]. Proposed aquaculture developments have been known to cause concern among local fishing communities [216]. Often, the concerns involve potential risks pertaining to the aquaculture development [217].

\section{MPPs and Risk}

The offshore environment is associated with high technical risks arising from the mechanical forces, corrosion, biofouling, extreme conditions and unreliable moorings [13].

Research investigating such risks is emerging, with the MARIBE project considering the technical and non-technical challenges associated with MPP including risk perceptions of new technologies and their combinations [14].

A simple methodology for assessing the risks associated with MPPs, considering operation, economic, environmental, socio-economic, financial, political and health and safety risks across the different phases of a project was presented [14].

The MERMAID project utilized the Policy, Economic, Social, Technical, Environmental and Legal (PESTEL) approach (also known as PESTLE), along with stakeholder analysis to gain a clearer understanding of external factors affecting future MPP developments [11]. This identified legal and policy, social, environmental, technical and economic issues as presenting key obstacles to MPP.

Legal and policy obstacles identified included complicated bureaucracy, poor dialogue between public institutions and difficulties identifying responsibilities for permits, and a lack of codes and standards [11]. Social obstacles refer to potential conflict with near-shore and offshore fisheries, tourism and shipping routes.

Further, activities that change the marine landscape were deemed socially unacceptable by stakeholders. However, some perceived social obstacles (e.g. anchoring issues) stem from a current lack of experience and understanding of ORE installations.

Other concerns are about insurance (costs may increase once the potential types of accidents insurers will have to cover become clearer) and the financial feasibility of combining 
some activities (e.g. mussel and seaweed farming with offshore wind farm (OWF)), due to the reluctance of OWF operators to share space due to potential risks arising from multiple uses.

While new jobs and revenue streams are obvious socio-economic benefits of MPP projects, there was also evidence of potential conflict with fishing communities and between wave energy production and energy suppliers, equipment and machinery, and marine transport. In particular, the offshore wind industry is concerned about potential risks (e.g. collision and corrosion) arising from MPP developments [218].

Such findings highlight the need for further research, investigating the potential socio-environmental-policy-technological risks, opportunities (e.g. new business models), challenges (e.g., barriers, and enabling mechanisms), trade-offs associated with MPPs, and their governance. Given the complex and multifaceted emergent properties, and trade-offs associated with the multiple activities that MPPs comprise, new trans-disciplinary methods, adopting systems approaches resilience-thinking, will be vital to overcome the limitations associated with traditional single discipline approaches [194, 219].

This will require consideration of critical systems functions, interactions and inter-dependencies, and their uncertainties, together with levels of robustness and resilience of the MPP and its component systems, across its life-cycle, under a range of conditions including low-frequency high consequence extreme events (e.g. typhoons and storm surges) [219]. Furthermore, greater consideration of cumulative effects, requiring new approaches to overcome recognized limitations in CEA practice are required [133, 134]. Such studies will support the identification of priority risks and monitoring, management and mitigation measures to reduce MPP risks and vulnerabilities.

In parallel research assessing the socio-environmental impacts and benefits of MPP is urgently required. Critically this should include consideration of societal acceptability and values, potentially affecting MPP development, and strategies for optimizing their benefits and reducing the risk of conflict. For example, siting MPP further offshore may avoid nearshore conflicts with sectors such as tourism and navigation [12]. This in turn will requires exploration of the governance challenges associated with MPP.

Here, it is argued that MPPs and co-location of activities could result in the development of a common regulatory framework, resulting in more co-ordinated marine spatial planning and simplified licensing procedures [13]. In parallel, with research highlighting a wide range of 
potential legal issues surrounding ORE [220], studies exploring the legal implications of MPP, notably liabilities and the potential need for new forms of business model, will be of importance to the sector.

\section{Overview and discussion}

As previously stated, due to the scarcity of references analyzing MPP systems, the scope of the review has been expanded also to research works analyzing single energy source systems/single aquaculture systems. 
Table 3: System classification of references

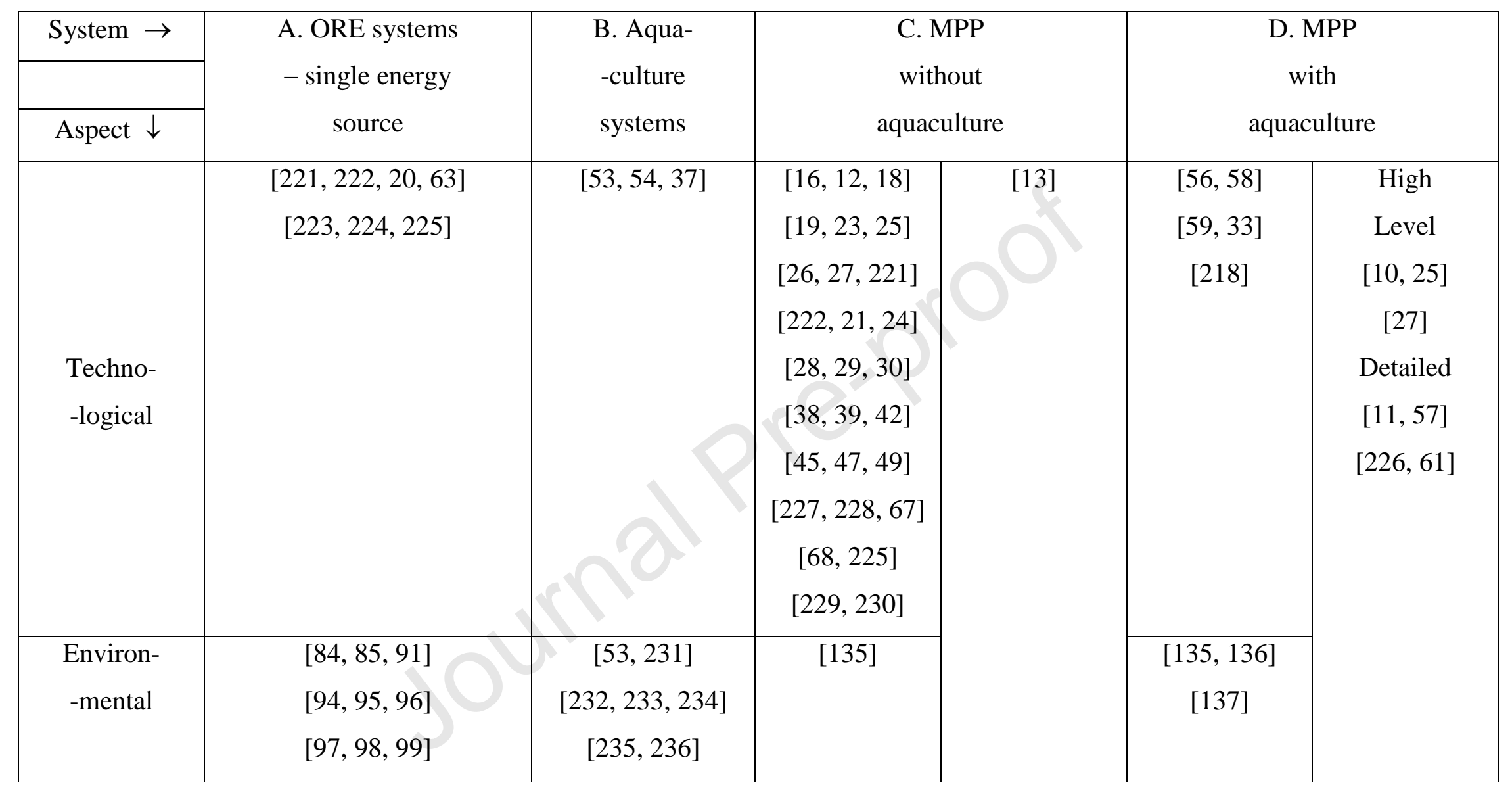




\begin{tabular}{|l|c|c|c|}
\hline & {$[15]$ (Wind) $[7,179]$} & {$[9,205,206]$} & {$[13,135]$} \\
Socio- & {$[180,181,185,186]$} & {$[207,208,209]$} & \\
-economic & {$[190,187,188,189]$} & {$[210,211]$} & \\
& (Wave) $[199]$ & (Policy) [238] & \\
& {$[201,191]$} & & \\
& (Policy) $[2,3]$ & &
\end{tabular}

\begin{tabular}{|c|}
\hline$[12,13]$ \\
{$[237,100]$} \\
{$[135]$} \\
(Policy) \\
{$[239]$}
\end{tabular}


In the synoptic Table 3, the references cited have been classified against the type of system analysed:

A ORE systems extracting energy only from one type of energy source (single purpose);

B Aquaculture (only) systems;

C MPP coupling offshore systems extracting renewable energy from two or more sources, but not coupled with aquaculture system/s;

D MPP coupling offshore systems extracting renewable energy from two or more sources, including aquaculture system/s;

and against the aspect/s considered, i.e. if mainly concentrating on the technological (engineering) aspects, the environmental impact aspects, the socio-economic aspects, or all of them.

\subsection{Main considerations on the literature reviewed}

Most of the research has been focused on the technological aspects of the MPP systems, followed by the socio-economic aspects, and then the environmental impact aspects. This can be explained by the Technology Readiness Level (TRL) of the research conducted in this area, which in most cases can be assessed as between TRL 2 amd TRL 6 , if the TRL scale used by Horizon 2020 EU funding scheme is adopted, reported in Table 4. As it can be seen, even if it is not the only aspect, from TRL 1 to TRL 6 the focus is on the technological aspects.

Table 4: Technology Readiness Level [240]

\begin{tabular}{|l|l|}
\hline TRL 1 & Basic principle observed \\
\hline TRL 2 & Technology concept formulated \\
\hline TRL 3 & Experimental proof of concept \\
\hline TRL 4 & Technology validated in lab \\
\hline TRL 5 & Technology validated in relevant environment \\
\hline TRL 6 & Technology demonstrated in relevant environment \\
\hline TRL 7 & System prototype demonstration in operational environment \\
\hline TRL 8 & System complete and qualified \\
\hline TRL 9 & Actual system proven in operational environment \\
\hline
\end{tabular}


An important first consideration following up from this one is indeed that, despite the substantial advantages obtained if both the environmental and the socio-economic aspects are considered from the early stage of the technology development, the need to adopt a multidisciplinary approach is still not common practice even for commercially mature systems, with only few noticeable examples [11, 14, 57, 61, 226].

The second consideration is that the research done on MPP has been much more focused on the so called 'hybrid' ORE systems, i.e. coupling wind, wave, and tidal systems, but considering the direct coupling or the close co-location of aquaculture systems in very few cases, especially when considering the technological aspects. The Blue Growth EU-funded projects have started to address this gap in knowledge, and MERMAID [27]), but have also highlighted the several multidisciplinary challenges to be tackled.

The third observation is that these European projects had been focusing on large commercial scale installations, MPP farms, consisting in installed capacities of the order of hundreds of MW to GW, connected to the grid and, whenever considered, aquaculture systems of commercial scale. Nonetheless, as demonstrated by some pilot projects in China (Daguan [221], Dawanshan [222], and Sehngshan [222]), there is a strong potential for small scale MPP to serve remote, isolated communities, providing not only a sustainable, safe, affordable source of energy, but also socio-economic benefits such as food and jobs.

Furthermore, also in the EU there is a growing research interest in coupling sustainable source of energy to offshore aquaculture facilities [36, 241]. The research on small scale MPP can certainly learn and build upon the ones done for large scale MPP farms, but it is likely that there will be some specific challenges. For example, the scale of the environmental impact is completely different, the metocean conditions will have a higher impact on the dynamic response of the MPP, and the dynamics of the different systems (wind, wave, solar, aquaculture) may be more strongly coupled. There is certainly a need for further research.

\section{Conclusion}

An emerging interest in the development of multi-purpose platforms, exploiting the synergies among ORE and aquaculture industries, has been observed over the past decade.

Based on this analysis, the following main points can be derived, which also constitute a 
statement of the current gaps in knowledge:

- In general, there is a scarcity of literature specifically on MPP systems, probably due to this technology's low TRL level, and the lack of full scale, but also small scale outdoor prototypes;

- Therefore, at the moment, this area of research has to rely on single-purpose, single discipline studies to develop a multidisciplinary analysis framework for MPP systems: the present article aims at providing an overview of the available material to develop such framework;

- If the number of sources on MPP can be considered proportional to the research effort, most of the effort so far has been allocated to the technological aspects (again, probably due to the low TRL level), while the socio-economic and environmental aspects have been investigated to a lower extent;

- The adoption of a multidisciplinary approach is still not common practice even for more mature, single-purpose offshore systems, with only few noticeable examples;

- The majority of the literature focuses on a small subset of MPP, coupling only different ORE devices, but not integrating or co-locating aquaculture systems, with only relatively few recent EU-funded projects that started to address this gap in knowledge;

\section{Acknowledgments}

This work is supported by the UK Engineering and Physical Sciences Research Council UK (EPSRC) and the Natural Environment Research Council UK (NERC), through grant EP/R007497/1, and the Natural Science Foundation of China (NSFC) through grant 51761135013. The authors are also thankful to Walid M. H. Nassar, Ph.D student at the University of Strathclyde, for reviewing the section on 'Control of MPP's.'

\section{References}

[1] World Energy Council, World Energy Trilemma - 2016 (accessed April 23, 2018).

URL

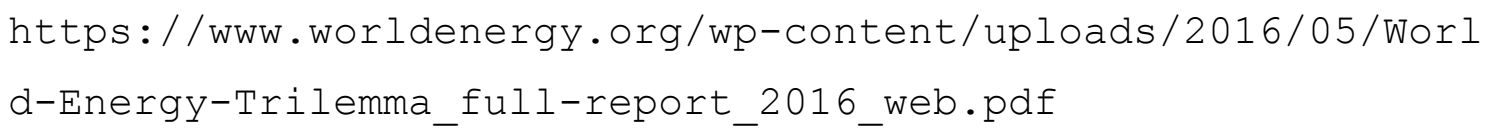


[2] H. Jeffrey, J. Sedgwick, ORECCA European offshore renewable energy roadmap, Edinburgh: Offshore Renewable Energy Conversion Platform Coordination Action Project (2011).

[3] EOEA, Oceans of energy: European Ocean Energy Roadmap 2010-2050, European Ocean Energy Association (2010).

[4] L. Mee, Complementary benefits of alternative energy: Suitability of offshore wind farms as aquaculture sites, Tech. Rep. SEAFISH - Project Ref: 10517, University of Plymouth (2006).

[5] T. Michler-Cieluch, G. Krause, Perceived concerns and possible management strategies for governing 'wind farm-mariculture integration', Marine Policy 32 (6) (2008) 1013-1022. doi:https://doi.org/10.1016/j.marpol.2008.02.008.

[6] T. Michler-Cieluch, G. Krause, B. H. Buck, Reflections on integrating operation and maintenance activities of offshore wind farms and mariculture, Ocean \& Coastal Management $\quad 52 \quad$ (1) 57-68. doi:https://doi.org/10.1016/j.ocecoaman.2008.09.008.

[7] S. Rodrigues, C. Restrepo, E. Kontos, R. T. Pinto, P. Bauer, Trends of offshore wind projects, Renewable and Sustainable Energy Reviews 49 (2015) 1114-1135. doi:https://doi.org/10.1016/j.rser.2015.04.092.

[8] FAO, State of World Aquaculture, Food \& Agriculture Organization, 2006.

[9] A. Drumm, Evaluation of the promotion of offshore aquaculture through a technology platform (OATP), Marine Institute, Galway, 2010.

[10] P. Holm, B. H. Buck, R. Langan, Introduction: New approaches to sustainable offshore food production and the development of offshore platforms, in: Aquaculture Perspective of Multi-Use Sites in the Open Ocean, Springer, 2017, pp. 1-20. doi:https://doi.org/10.1007/978-3-319-51159-7_1.

[11] M. Stuiver, K. Soma, P. Koundouri, S. van den Burg, A. Gerritsen, T. Harkamp, N. Dalsgaard, F. Zagonari, R. Guanche, J.-J. Schouten, S. Hommes, A. Giannouli, T. Söderqvist, L. Rosen, R. Garção, J. Norrman, C. Röckmann, M. de Bel, B. Zanuttigh, O. Petersen, F. Møhlenberg, The governance of multi-use platforms at sea for energy production and aquaculture: Challenges for policy makers in European Seas, Sustainability 8 (4) (2016)333. doi:https: / doi.org/10.3390/su8 840333. 
[12] A. Stefanakou, I. Dagkinis, T. Lilas, A. Maglara, A. Vatistas, Development of a floating wind-desalination multi-use platform (MUP) in the context of optimal use of maritime space, in: Offshore energy and storage symposium (OSES), University of Malta, 2016.

[13] B. Zanuttigh, E. Angelelli, G. Bellotti, A. Romano, Y. Krontira, D. Troianos, R. Suffredini, G. Franceschi, M. Cantù, L. Airoldi, F. Zagonari, A. Taramelli, F. Filipponi, C. Jimenez, M. Evriviadou, S. Broszeit, Boosting blue growth in a mild sea: Analysis of the synergies produced by a multi-purpose offshore installation in the Northern Adriatic, Italy, Sustainability $\quad 7 \quad(6)$ (2015) 6804-6853. doi:https://doi.org/10.3390/su7066804.

[14] H. E. Williams, I. Masters, D. Pletsas, C. F. Grunewald, R. Callaway, M. Blanch, G. Dalton, A risk assessment methodology for combining marine renewables with other blue economy activities via multi-use of spaces and platforms, in: 12th European Wave and Tidal Energy Conference, EWTEC, 2017, pp. 817-1 - 817-9.

[15] J. P. Praene, M. David, F. Sinama, D. Morau, O. Marc, Renewable energy: Progressing towards a net zero energy island, the case of Reunion Island, Renewable and Sustainable $\begin{array}{lllll}\text { Energy } & \text { Reviews } & 16 & \text { (1) }\end{array}$ doi:https://doi.org/10.1016/j.rser.2011.08.007.

[16] M. Veigas, G. Iglesias, Potentials of a hybrid offshore farm for the island of Fuerteventura, Energy Conversion and Management 86 (2014) 300-308. doi:https://doi.org/10.1016/j.enconman.2014.05.032.

[17] M. F. Schupp, M. Bocci, D. Depellegrin, A. Kafas, Z. Kyriazi, I. Lukic, A. Schultz-Zehden, G. Krause, V. Onyango, B. H. Buck, Towards a common understanding of ocean multi-use, Frontiers in Marine Science 6 (2019) 165. doi:https://doi.org/10.3389/fmars.2019.00165.

[18] C. Pérez-Collazo, D. Greaves, G. Iglesias, A review of combined wave and offshore wind energy, Renewable and Sustainable Energy Reviews 42 (2015) 141-153. doi:https://doi.org/10.1016/j.rser.2014.09.032.

[19] M. J. Muliawan, M. Karimirad, T. Moan, Dynamic response and power performance of a combined spar-type floating wind turbine and coaxial floating wave energy converter, $\begin{array}{llll}\text { Renewable } & \text { Energy } & 50 & \text { (2013) }\end{array}$ doi:https://doi.org/10.1016/j.renene.2012.05.025. 
[20] J. M. Jonkman, S. Butterfield, W. Musial, G. Scott, Definition of a 5-MW reference wind turbine for offshore system development, Tech. Rep. NREL/TP-500-38060, National Renewable Energy Laboratory, Golden, Colorado (2009).

[21] C. Michailides, C. Luan, Z. Gao, T. Moan, Effect of flap type wave energy converters on the response of a semi-submersible wind turbine in operational conditions, in: ASME 2014 33rd International Conference on Ocean, Offshore and Arctic Engineering, American Society of Mechanical $\quad 2014$. doi:https://doi.org/10.1115/OMAE2014-24065.

[22] K. O’Sullivan, J. Murphy, Techno-economic optimisation of an oscillating water column array wave energy converter, in: 10th European Wave and Tidal Energy Conference (EWTEC), Vol. 1, European Wave and Tidal Energy Committees, Aalborg, Denmark, 2013, pp. 1-8.

[23] C. Casale, L. R. Serri, N. E. Stolk, I. Yildiz, C. M. E. I. e Innovazione, Synergies, innovative designs and concepts for multipurpose use of conversion platforms, Tech. rep., Results of ORECCA Project-WP4 (FP7) (2012).

[24] A. B. Da Rocha, F. J. Lino, N. Correia, J. C. Matos, M. Marques, T. Morais, Offshore renewable energy development of ocean technology projects at INEGI, in: VIth Cuban Congress on Mechanical Engineering and Metallurgy, 2010.

[25] E. Quevedo, M. Cartón, E. Delory, A. Castro, J. Hernández, O. Llinás, J. de Lara, N. Papandroulakis, P. Anastasiadis, J. Bard, H. Jeffrey, D. Ingram, J. Wesnigk, Multi-use offshore platform configurations in the scope of the FP7 TROPOS Project, in: OCEANS-Bergen, 2013 MTS/IEEE, IEEE, 2013, pp. 1-7.

[26] H2Ocean Website, Development of a wind-wave power open-sea platform equipped for hydrogen generation with support for multiple users of energy (accessed February 15, 2018).

URL http: / / www.h2ocean-project.eu/

[27] E. D. Christensen, M. Stuiver, R. Guanche, F. Møhlenberg, J.-J. Schouten, O. S. Pedersen, W. He, B. Zanuttigh, P. Koundouri, Go offshore-Combining food and energy production, Technical University of Denmark, 2015.

[28] J. E. Hanssen, L. Margheritini, K. O’Sullivan, P. Mayorga, I. Martinez, A. Arriaga, I. Agos, J. Steynor, D. Ingram, R. Hezari, J. H. Todalshaug, Design and performance 
validation of a hybrid offshore renewable energy platform, in: Tenth International Conference on Ecological Vehicles and Renewable Energies (EVER), IEEE, 2015, pp. 1-8. doi:10.1109/EVER.2015.7113017.

[29] A. Peiffer, D. Roddier, Design of an oscillating wave surge converter on the WindFloat structure, in: 4th International Conference on Ocean Energy, 2012.

[30] A. Yde, M. M. Pedersen, S. Bellew, A. Køhler, R. S. Clausen, A. W. Nielsen, Experimental and theoretical analysis of a combined floating wave and wind energy conversion platform, Tech. Rep. 0044, DTU Wind Energy (2014).

[31] H. Soerensen, E. Friis-Madsen, I. Russel, S. Parmeggiani, J. Fernández-Chozas, Feasibility and LCA for a Wave Dragon platform with wind turbines, in: The 26th International Ocean and Polar Engineering Conference, International Society of Offshore and Polar Engineers, 2016, pp. 570-575.

[32] I. Russell, E. Friis-Madsen, H. Soerensen, Wave Dragon - 'Coldward and Stormward', in: Proceedings of the 2nd International Conference on Renewable Energies Offshore, Lisbon, Portugal, 2016, pp. 249-254.

[33] ECOFYS, Marine parks: Sketch for sustainable energy and biomass at sea, Tech. Rep. 08.2.168, [in Dutch] (2008).

[34] N. Papandroulakis, C. Thomsen, K. Mintenbeck, P. Mayorga, J. J. Hernández-Brito, The EU-Project "TROPOS", in: Aquaculture Perspective of Multi-Use Sites in the Open Ocean, $\quad$ Springer, $2017, \quad$ pp. 355-374. doi:https://doi.org/10.1007/978-3-319-51159-7_12.

[35] MERMAID, Integration of energy converters in multi-use offshore platforms, Tech. Rep. D 3.4, mermaidproject.eu (2015).

[36] H. L. Syse, Investigating off-grid energy solutions for the salmon farming industry, Master's thesis, University of Strathclyde and Universitetet i Stavanger (2016).

[37] EXPOSED, Aquaculture Operations - Annual Report, Tech. rep., The Research Council of Norway, Trondheim, Norway (2017).

[38] C. Michailides, Z. Gao, T. Moan, Experimental and numerical study of the response of the offshore combined wind/wave energy concept SFC in extreme environmental conditions, Marine Structures $\quad 50 \quad$ 35-54. doi:https://doi.org/10.1016/j.marstruc.2016.06.005. 
[39] Z. Gao, T. Moan, L. Wan, C. Michailides, Comparative numerical and experimental study of two combined wind and wave energy concepts, Journal of Ocean Engineering and Science 1 (2016) $36-51$. doi:https://doi.org/10.1016/j.joes.2015.12.006.

[40] MARINTEK, SIMO User's Manual, Trondheim, Norway (2011).

[41] MARINTEK, RIFLEX User's Manual, Trondheim, Norway (2013).

[42] M. Karimirad, K. Koushan, WindWEC: Combining wind and wave energy inspired by Hywind and Wavestar, in: International Conference on Renewable Energy Research and Applications (ICRERA), IEEE, 2016, pp. 96-101. doi:10.1109/ICRERA.2016.7884433.

[43] J. Jonkman, Definition of the Floating System for Phase IV of OC3, Tech. Rep. NREL/TP-500-47535, National Renewable Energy Laboratory, Golden, Colorado (2010).

[44] M. Kramer, L. Marquis, P. Frigaard, Performance evaluation of the Wavestar prototype, in: European Wave and Tidal Energy Conference, University of Southampton, Southampton, UK, 2011.

[45] T. Soulard, A. Babarit, B. Borgarino, M. Wyns, M. Harismendy, C-HYP: A combined wave and wind energy platform with balanced contributions, in: 32nd International Conference on Ocean, Offshore and Arctic Engineering, Nantes, France, 2013. doi:https://doi.org/10.1115/OMAE2013-10778.

[46] M. Karimirad, T. Moan, A simplified method for coupled analysis of floating offshore wind turbines, Marine Structures 27 (1) (2012) 45-63. doi:https://doi.org/10.1016/j.marstruc.2012.03.003.

[47] J. A. Armesto, J. Sarmiento, V. Ayllón, A. Iturrioz, A. Jurado, R. Guanche, I. J. Losada, Numerical and experimental study of a multi-use platform, in: 35th International Conference on Ocean, Offshore and Arctic Engineering, American Society of Mechanical Engineers, Busan, South Korea, 2016, pp. V006T09A018-V006T09A018. doi:https://doi.org/10.1115/OMAE2016-54427.

[48] A. Babarit, G. Delhommeau, Theoretical and numerical aspects of the open source BEM solver NEMOH, in: 11th European Wave and Tidal Energy Conference, École Centrale de Nantes, Nantes, France, 2015.

[49] L. Li, Y. Gao, Z. Yuan, S. Day, Z. Hu, Dynamic response and power production of a 
floating integrated wind, wave and tidal energy system, Renewable Energy 116 (2018) 412-422. doi:https://doi.org/10.1016/j.renene.2017.09.080.

[50] A. Bahaj, W. Batten, G. McCann, Experimental verifications of numerical predictions for the hydrodynamic performance of horizontal axis marine current turbines, Renewable $\begin{array}{lllll}\text { energy } & 32 & \text { (15) 2479-2490. }\end{array}$ doi:https://doi.org/10.1016/j.renene.2007.10.001.

[51] C. Michailides, Z. Gao, T. Moan, Experimental study of the functionality of a semisubmersible wind turbine combined with flap-type wave energy converters, Renewable $\quad 93 \quad$ Energy $\quad 93$ 675-690. doi:https://doi.org/10.1016/j.renene.2016.03.024.

[52] L. Wan, Z. Gao, T. Moan, C. Lugni, Comparative experimental study of the survivability of a combined wind and wave energy converter in two testing facilities, Ocean Engineering 111 (2016) 82-94. doi:https://doi.org/10.1016/j.oceaneng.2015.10.045.

[53] H. F. Upton, E. H. Buck, Open ocean aquaculture, Congressional Research Service, 2010.

[54] J. Ryan, Farming the deep blue, Marine Institute - Ireland, 2004.

[55] Y. Chu, C. Wang, J. Park, P. Lader, Review of cage and containment tank designs for $\begin{array}{lllll}\text { offshore } & \text { fish } & \text { farming, } & \text { Aquaculture } & \text { (2020) }\end{array}$ doi:https://doi.org/10.1016/j.aquaculture.2020.734928.

[56] N. Goseberg, B. Franz, T. Schlurmann, The potential co-use of aquaculture and offshore wind energy structures, in: Proceedings of the Sixth Chinese-German Joint Symposium on Hydraulic and Ocean Engineering (CGJOINT 2012), Vol. 6, 2012, pp. 597-603.

[57] MARIBE, Unlocking the potential of multi-use of space and multi-use platforms (accessed April 28, 2018).

URL

http: //maribe.eu/wp-content/uploads/2016/09/maribe-booklet. $\operatorname{pdf}$

[58] Á. Viúdez, M. F.-P. Balsells, R. Rodrguez-Marroyo, Artificial upwelling using offshore wind energy for mariculture applications, Scientia Marina 80 (S1) (2016) 235-248. doi:http://dx.doi.org/10.3989/scimar.04297.06B.

[59] O. Langhamer, D. Wilhelmsson, Colonisation of fish and crabs of wave energy 
foundations and the effects of manufactured holes-a field experiment, Marine Environmental Research $68 \quad$ (4) 151-157. doi:https://doi.org/10.1016/j.marenvres.2009.06.003.

[60] L. Recalde, H. Yue, W. Leithead, O. Anaya-Lara, H. Liu, J. You, Hybrid renewable energy systems sizing for offshore multi-purpose platforms, in: 38th International Conference on $\begin{array}{llll}\text { Ocean, } & \text { Offshore } \quad \& \quad \text { Arctic } & \end{array}$ doi:https://doi.org/10.1115/OMAE2019-96017.

[61] B. Zanuttigh, E. Angelelli, A. Kortenhaus, K. Koca, Y. Krontira, P. Koundouri, A methodology for multi-criteria design of multi-use offshore platforms for marine renewable energy harvesting, Renewable Energy 85 (2016) 1271-1289. doi:https://doi.org/10.1016/j.renene.2015.07.080.

[62] R. Cozzolino, L. Tribioli, G. Bella, Power management of a hybrid renewable system for artificial islands: A case study, Energy $106 \quad$ (2016) 774-789. doi:https://doi.org/10.1016/j.energy.2015.12.118.

[63] J. V. Ringwood, S. Simani, Overview of modelling and control strategies for wind turbines and wave energy devices: Comparisons and contrasts, Annual Reviews in Control 40 (2015)

doi:https://doi.org/10.1016/j.arcontrol.2015.09.003.

[64] A. Zeng, Q. Xu, M. Ding, K. Yukita, K. Ichiyanagi, A classification control strategy for energy storage system in microgrid, IEEJ Transactions on Electrical and Electronic $\begin{array}{llll}\text { Engineering } & 10 & \text { (4) 396-403. }\end{array}$ doi:https://doi.org/10.1002/tee.22099.

[65] K.-H. Kim, K. Lee, J. M. Sohn, S.-W. Park, J.-S. Choi, K. Hong, Conceptual design of 10MW class floating wave-offshore wind hybrid power generation system, in: The Twenty-fifth International Ocean and Polar Engineering Conference, International Society of Offshore and Polar Engineers, 2015.

[66] C. Natesan, S. K. Ajithan, S. Chozhavendhan, A. Devendiran, Power management strategies in microgrid: A survey, International Journal Of Renewable Energy Research 5 (2) (2016) 334-340.

[67] A. Mohanty, M. Viswavandya, P. K. Ray, S. Mohanty, Reactive power control and optimisation of hybrid off shore tidal turbine with system uncertainties, Journal of Ocean 
Engineering and Science $1 \quad$ (4) 256-267. doi:https://doi.org/10.1016/j.joes.2016.06.005.

[68] O. Erdinc, M. Uzunoglu, Optimum design of hybrid renewable energy systems: Overview of different approaches, Renewable and Sustainable Energy Reviews 16 (3) (2012) 1412-1425. doi:https://doi.org/10.1016/j.rser.2011.11.011.

[69] A. Bidram, A. Davoudi, Hierarchical structure of microgrids control system, IEEE Transactions on Smart Grid 3 (4) (2012) 1963-1976. doi:10.1109/TSG.2012.2197425.

[70] Z. Zhou, M. Benbouzid, J. F. Charpentier, F. Scuiller, T. Tang, A review of energy storage technologies for marine current energy systems, Renewable and Sustainable Energy Reviews $18 \quad$ 390-400. doi:https://doi.org/10.1016/j.rser.2012.10.006.

[71] S. Cao, L. Fu, X. Wang, H. Liu, Research on optimal access of fluctuation source and storage device in DN based on statistical and fuzzy theory, in: 8th International Power Electronics and Motion Control Conference (IPEMC 2016-ECCE Asia), Institute of Electrical and Electronics Engineers (IEEE), 2016, pp. 201-206. doi:10.1109/IPEMC.2016.7512285.

[72] G. J. Osório, E. M. G. Rodrigues, J. M. Lujano-Rojas, J. C. O. Matias, J. P. S. Catalão, New control strategy for the weekly scheduling of insular power systems with a battery energy storage system, Applied Energy $154 \quad$ (2015) 459-470. doi:https://doi.org/10.1016/j.apenergy.2015.05.048.

[73] C. K. Simoglou, E. G. Kardakos, E. A. Bakirtzis, D. I. Chatzigiannis, S. I. Vagropoulos, A. V. Ntomaris, P. N. Biskas, A. Gigantidou, E. J. Thalassinakis, A. G. Bakirtzis, J. P. S. Catalão, An advanced model for the efficient and reliable short-term operation of insular electricity networks with high renewable energy sources penetration, Renewable and Sustainable $\quad$ Energy $\quad$ Reviews $38 \quad$ (2014) 415-427. doi:https://doi.org/10.1016/j.rser.2014.06.015.

[74] S. Koohi-Kamali, N. A. Rahim, H. Mokhlis, Smart power management algorithm in microgrid consisting of photovoltaic, diesel, and battery storage plants considering variations in sunlight, temperature, and load, Energy Conversion and Management 84 (2014) 
doi:https://doi.org/10.1016/j.enconman.2014.04.072.

[75] D. Magagna, A. Uihlein, Ocean energy development in Europe: Current status and future perspectives, International Journal of Marine Energy 11 (2015) 84-104. doi:https://doi.org/10.1016/j.ijome.2015.05.001.

[76] B. Zhao, X. Zhang, P. Li, K. Wang, M. Xue, C. Wang, Optimal sizing, operating strategy and operational experience of a stand-alone microgrid on Dongfushan Island, Applied Energy $113 \quad$ (2014) 1656-1666. doi:https://doi.org/10.1016/j.apenergy.2013.09.015.

[77] N. Hatziargyriou, Microgrids: architectures and control, John Wiley \& Sons, 2014.

[78] O. Erdinc, N. G. Paterakis, J. P. S. Catalão, Overview of insular power systems under increasing penetration of renewable energy sources: Opportunities and challenges, Renewable and Sustainable Energy Reviews 52 (2015) 333-346. doi:https://doi.org/10.1016/j.rser.2015.07.104.

[79] J. Sachs, O. Sawodny, A two-stage model predictive control strategy for economic diesel-PV-battery island microgrid operation in rural areas, IEEE Transactions on Sustainable Energy 7 (3) (2016) 903-913. doi:10.1109/TSTE.2015.2509031.

[80] L. Zhang, X. He, H. Xin, Z. Wang, D. Gan, Hierarchical control design and verification of a multi-mode microgrid on the Zhairuoshan Island, in: Power and Energy Society General Meeting (PESGM), 2016, IEEE, 2016, pp. 1-5. doi:10.1109/PESGM.2016.7741089.

[81] C. E. Lin, B. C. Phan, Optimal hybrid energy solution for island micro-grid, in: International Conferences on Big Data and Cloud Computing (BDCloud), Social Computing and Networking (SocialCom), Sustainable Computing and Communications (SustainCom)(BDCloud-SocialCom-SustainCom), IEEE, 2016, pp. 461-468. doi:10.1109/BDCloud-SocialCom-SustainCom.2016.74.

[82] S. Xie, R. Zhai, X. Liu, B. Li, K. Long, Q. Ai, Self-adaptive genetic algorithm and fuzzy decision based multi-objective optimization in microgrid with DGs, The Open Electrical \& Electronic Engineering Journal 10 (1) (2016) 46-57.

[83] K. A. Alexander, S. A. Meyjes, J. J. Heymans, Spatial ecosystem modelling of marine renewable energy installations: Gauging the utility of Ecospace, Ecological Modelling 331 (2016)

$115-128$. 
doi:https://doi.org/10.1016/j.ecolmodel.2016.01.016.

[84] G. W. Boehlert, A. B. Gill, Environmental and ecological effects of ocean renewable energy development: A current synthesis, Oceanography 23 (2) (2010) 68-81. doi:https://doi.org/10.5670/oceanog.2010.46.

[85] A. L. Drewitt, R. H. W. Langston, Assessing the impacts of wind farms on birds, IBIS 148 (s1)

(2006)

$29-42$.

doi:https://doi.org/10.1111/j.1474-919x.2006.00516.x.

[86] Polaris Wind Power Network, The demolition of all 48 Taiwan wind turbines in Long Island, Shandong Province, in Chinese (accessed May 29, 2018).

URL http://news.bjx.com.cn/html/20170821/844599.shtml.

[87] P. T. Madsen, M. Wahlberg, J. Tougaard, K. Lucke, P. Tyack, Wind turbine underwater noise and marine mammals: implications of current knowledge and data needs, Marine Ecology Progress Series 309 (2006) 279-295. doi:10 . 3354 /meps309279.

[88] J. Tougaard, O. D. Henriksen, L. A. Miller, Underwater noise from three types of offshore wind turbines: Estimation of impact zones for harbor porpoises and harbor seals, The Journal of the Acoustical Society of America 125 (6) (2009) 3766-3773. doi:https://doi.org/10.1121/1.3117444.

[89] H. Bailey, B. Senior, D. Simmons, J. Rusin, G. Picken, P. M. Thompson, Assessing underwater noise levels during pile-driving at an offshore windfarm and its potential effects on marine mammals, Marine Pollution Bulletin 60 (6) (2010) 888-897. doi:https://doi.org/10.1016/j.marpolbul.2010.01.003.

[90] M. J. Brandt, A. Diederichs, K. Betke, G. Nehls, Responses of harbour porpoises to pile driving at the Horns Rev II offshore wind farm in the Danish North Sea, Marine Ecology $\begin{array}{lllll}\text { Progress } & \text { Series } & 421 & \text { 2011) }\end{array}$ doi:https://doi.org/10.3354/meps08888.

[91] S. Koschinski, B. M. Culik, O. D. Henriksen, N. Tregenza, G. Ellis, C. Jansen, G. Kathe, Behavioural reactions of free-ranging porpoises and seals to the noise of a simulated $2 \mathrm{MW}$ windpower generator, Marine Ecology Progress Series 265 (2003) 263-273. doi:10.3354/meps265263.

[92] F. Thomsen, K. Lüdemann, R. Kafemann, W. Piper, Effects of offshore wind farm noise on marine mammals and fish, Tech. rep., Biola, Hamburg, Germany on behalf of COWRIE 
$\operatorname{Ltd}$ (2006).

[93] R. Kikuchi, Risk formulation for the sonic effects of offshore wind farms on fish in the EU region, Marine Pollution Bulletin 60 (2) (2010) 172-177. doi:https://doi.org/10.1016/j.marpolbul.2009.09.023.

[94] M. Wahlberg, H. Westerberg, Hearing in fish and their reactions to sounds from offshore wind farms, Marine Ecology Progress Series 288 (2005) 295-309. doi:10.3354/meps288295.

[95] W. J. Grecian, R. Inger, M. J. Attrill, S. Bearhop, B. J. Godley, M. J. Witt, S. C. Votier, Potential impacts of wave-powered marine renewable energy installations on marine birds, IBIS $152 \quad$ (4) 683-697. doi:https://doi.org/10.1111/j.1474-919x.2010.01048.x.

[96] R. Inger, M. J. Attrill, S. Bearhop, A. C. Broderick, W. James Grecian, D. J. Hodgson, C. Mills, E. Sheehan, S. C. Votier, M. J. Witt, B. J. Godley, Marine renewable energy: potential benefits to biodiversity? An urgent call for research, Journal of Applied Ecology 46 (2009) 1145-1153. doi:https://doi.org/10.1111/j.1365-2664.2009.01697.x.

[97] D. Wilhelmsson, T. Malm, M. C. Öhman, The influence of offshore windpower on demersal fish, ICES Journal of Marine Science 63 (5) (2006) 775-784. doi:https://doi.org/10.1016/j.icesjms.2006.02.001.

[98] E. A. S. Linley, T. A. Wilding, K. Black, A. J. S. Hawkins, S. Mangi, Review of the reef effects of offshore wind farm structures and their potential for enhancement and mitigation, Tech. Rep. RFCA/005/0029P, PML Applications Ltd and SAMS (2007).

[99] O. Langhamer, D. Wilhelmsson, J. Engström, Artificial reef effect and fouling impacts on offshore wave power foundations and buoys-a pilot study, Estuarine, Coastal and Shelf $\begin{array}{llll}\text { Science } & 82 & \text { (3) } & \text { (2009) }\end{array}$ doi:https://doi.org/10.1016/j.ecss.2009.02.009.

[100] A. H. Fayram, A. de Risi, The potential compatibility of offshore wind power and fisheries: An example using bluefin tuna in the Adriatic Sea, Ocean \& Coastal Management 50 (8) (2007) 597-605. doi:https://doi.org/10.1016/j.ocecoaman.2007.05.004.

[101] T. Dempster, P. Sanchez-Jerez, J. T. Bayle-Sempere, F. Giménez-Casalduero, C. Valle, 
Attraction of wild fish to sea-cage fish farms in the south-western Mediterranean Sea: spatial and short-term temporal variability, Marine Ecology Progress Series 242 (2002) 237-252. doi:10.3354/meps 242237.

[102] P. Tett, S. Benjamins, K. D. Black, M. Coulson, K. Davidson, T. Fernandes, C. Fox, M. Hart, N. Hicks, A. Hughes, D.-C. Hunter, T. Nickell, D. Risch, D. Tocher, L. L. Vare, E. Verspoor, T. Wilding, B. Wilson, A. Wittich, Review of the environmental impacts of salmon farming in Scotland. A Report by SAMS Research Services Limited for the Environment, Climate Change and Land Reform (ECCLR) Committee), Tech. Rep. 02468-0001, The Scottish Parliament (2018).

[103] M. J. Costello, Ecology of sea lice parasitic on farmed and wild fish, Trends in Parasitology 22

$475-483$.

doi:https://doi.org/10.1016/j.pt.2006.08.006.

[104] P. A. Bjørn, R. Sivertsgård, B. Finstad, R. Nilsen, R. M. Serra-Llinares, R. Kristoffersen, Area protection may reduce salmon louse infection risk to wild salmonids, Aquaculture Environment Interactions 13 233-244. doi:https://doi.org/10.3354/aei00023.

[105] I. P. Helland, I. Uglem, P. A. Jansen, O. H. Diserud, P. A. Bjørn, B. Finstad, Statistical and ecological challenges of monitoring parasitic salmon lice infestations in wild salmonid fish stocks, Aquaculture Environment Interactions 7 (3) (2015) 267-280. doi:https://doi.org/10.3354/aei00155.

[106] P. Gargan, S. Shephard, C. Macintyre, Assessment of the increased mortality risk and population regulating effect of sea lice (Lepeophtheirus salmonis) from marine salmon farms on wild sea trout in Ireland and Scotland, in: G. Harris (Ed.), Sea trout: Science \& Management, 2017, pp. 507-522.

[107] A. Ferguson, I. A. Fleming, K. Hindar, Ø. Skaala, P. Mcginnity, T. Cross, P. Prodöhl, Farm Escapes, in: E. Verspoor, L. Stradmeyer, J. L. Nielsen (Eds.), The Atlantic salmon: genetics, conservation and management, Blackwell Publishing, Oxford, 2007, Ch. 12, pp. $357-398$.

[108] Ø. Skaala, K. A. Glover, B. T. Barlaup, T. Svåsand, F. Besnier, M. M. Hansen, R. Borgstrøm, Performance of farmed, hybrid, and wild Atlantic salmon (Salmo salar) families in a natural river environment, Canadian Journal of Fisheries and Aquatic 
$\begin{array}{lllll}\text { Sciences } & 69 & (12) & \text { (2012) }\end{array}$

doi:https://doi.org/10.1139/f2012-118.

[109] L. Sundt-Hansen, J. Huisman, H. Skoglund, K. Hindar, Farmed Atlantic salmon Salmo salar L. parr may reduce early survival of wild fish, Journal of Fish Biology 86 (6) (2015) 1699-1712. doi:https://doi.org/10.1111/jfb.12677.

[110] K. A. Glover, C. Pertoldi, F. Besnier, V. Wennevik, M. Kent, Ø. Skaala, Atlantic salmon populations invaded by farmed escapees: quantifying genetic introgression with a Bayesian approach and SNPs, BMC Genetics 14 (1) (2013) 74. doi:https://doi.org/10.1186/1471-2156-14-74.

[111] S. Karlsson, O. H. Diserud, P. Fiske, K. Hindar, Widespread genetic introgression of escaped farmed Atlantic salmon in wild salmon populations, ICES Journal of Marine $\begin{array}{llll}\text { Science } & 73 & \text { (10) }\end{array}$ doi:https://doi.org/10.1093/icesjms/fsw121.

[112] E. Mente, J. C. Martin, I. Tuck, K. A. Kormas, M. B. Santos, N. Bailey, G. J. Pierce, Mesoscale effects of aquaculture installations on benthic and epibenthic communities in four Scottish sea lochs, Aquatic Living Resources 23 (3) (2010) 267-276. doi:https://doi.org/10.1051/alr/2010030.

[113] N. B. Keeley, C. K. Macleod, G. A. Hopkins, B. M. Forrest, Spatial and temporal dynamics in macrobenthos during recovery from salmon farm induced organic enrichment: When is recovery complete?, Marine Pollution Bulletin 80 (2014) 250-262. doi:https://doi.org/10.1016/j.marpolbul.2013.12.008.

[114] P. A. Gillibrand, C. J. Cromey, K. D. Black, M. E. Inall, S. J. Gontarek, Identifying the risk of deoxygenation in Scottish sea lochs with isolated deep water, in: Scottish Aquaculture Research Forum, SARF, Vol. 7, 2006.

[115] P. Tett, V. Edwards, Review of harmful algal blooms in Scottish coastal waters, Tech. rep., Scottish Environmental Protection Agency (2002).

[116] L. Rydberg, B. Sjöberg, A. Stigebrandt, The interaction between fish farming and algal communities of the Scottish waters: A review, Tech. rep., Scottish Executive Environment Group Research (2003).

[117] T. J. Smayda, Harmful algal bloom communities in Scottish coastal waters: Relationship to fish farming and regional comparisons: A review, Tech. rep., Scottish Executive 
Environment Group Research (2006).

[118] M. J. Costello, A. Grant, I. M. Davies, S. Cecchini, S. Papoutsoglou, D. Quigley, M. Saroglia, The control of chemicals used in aquaculture in Europe, Journal of Applied $\begin{array}{lllll}\text { Ichthyology } & 17 & \text { (4) } & \text { (2001) }\end{array}$ doi:https://doi.org/10.1046/j.1439-0426.2001.00314.x.

[119] L. Burridge, J. S. Weis, F. Cabello, J. Pizarro, K. Bostick, Chemical use in salmon aquaculture: A review of current practices and possible environmental effects, Aquaculture 306 (2010) $7-23$.

doi:https://doi.org/10.1016/j.aquaculture.2010.05.020.

[120] S. Northridge, A. Coram, J. Gordon, Investigations on seal depredation at Scottish fish farms, Tech. rep., Edinburgh: Scottish Government (2013).

[121] A. Coram, J. Gordon, D. Thompson, S. Northridge, Evaluating and assessing the relative effectiveness of non-lethal measures, including acoustic deterrent devices, on marine mammals, Tech. rep., Scottish Government (2014).

[122] N. J. Quick, S. J. Middlemas, J. D. Armstrong, A survey of antipredator controls at marine salmon farms in Scotland, Aquaculture 230 (2004) 169-180. doi:https://doi.org/10.1016/S0044-8486(03)00428-9.

[123] P. F. Olesiuk, L. M. Nichol, M. J. Sowden, J. K. Ford, Effect of the sound generated by an acoustic harassment device on the relative abundance and distribution of harbor porpoises (Phocoena phocoena) in Retreat Passage, British Columbia, Marine Mammal Science 18 (4)

doi:https://doi.org/10.1111/j.1748-7692.2002.tb01077.x.

[124] M. J. Brandt, C. Höschle, A. Diederichs, K. Betke, R. Matuschek, S. Witte, G. Nehls, Far-reaching effects of a seal scarer on harbour porpoises, Phocoena phocoena, Aquatic Conservation: Marine and Freshwater Ecosystems 23 (2) (2013) 222-232. doi:https://doi.org/10.1002/aqc.2311.

[125] M. Holmer, Environmental issues of fish farming in offshore waters: perspectives, concerns and research needs, Aquaculture Environment Interactions 1 (1) (2009) 57-70. doi:https://doi.org/10.3354/aei00007.

[126] J. Liu, Y. Cui, J. Liu, Advances in studies on the effect of cage culture on the environment, Acta Hydrobiologica Sinica 21 (1997) 174-184. 
[127] P. A. Azevedo, C. L. Podemski, R. H. Hesslein, S. E. M. Kasian, D. L. Findlay, D. P. Bureau, Estimation of waste outputs by a rainbow trout cage farm using a nutritional approach and monitoring of lake water quality, Aquaculture 311 (1-4) (2011) 175-186. doi:https://doi.org/10.1016/j.aquaculture.2010.12.001.

[128] H. Cai, L. G. Ross, T. C. Telfer, C. Wu, A. Zhu, S. Zhao, M. Xu, Modelling the nitrogen loadings from large yellow croaker (Larimichthys crocea) cage aquaculture, Environmental Science and Pollution Research 23 (8) (2016) 7529-7542. doi:https://doi.org/10.1007/s11356-015-6015-0.

[129] X. Wang, L. M. Olsen, K. I. Reitan, Y. Olsen, Discharge of nutrient wastes from salmon farms: environmental effects, and potential for integrated multi-trophic aquaculture, Aquaculture Environment Interactions 2 (3) (2012) 267-283. doi:https://doi.org/10.3354/aei00044.

[130] J. G. Ferreira, H. C. Andersson, R. A. Corner, X. Desmit, Q. Fang, E. D. de Goede, S. B. Groom, H. Gu, B. G. Gustafsson, A. J. S. Hawkins, R. Hutson, H. Jiao, D. Lan, J. Lencart-Silva, R. Li, X. Liu, Q. Luo, J. K. Musango, A. M. Nobre, J. P. Nunes, P. L. Pascoe, J. G. C. Smits, A. Stigebrandt, T. C. Telfer, M. P. de Wit, X. Yan, X. L. Zhang, Z. Zhang, M. Y. Zhu, C. B. Zhu, S. B. Bricker, Y. Xiao, S. Xu, C. E. Nauen, M. Scalet, Sustainable Options for People, Catchment and Aquatic Resources (SPEAR), Tech. Rep. INCO-CT-2004-510706, Institute of Marine Research, Bergen, Norway (2015).

[131] H. Ackefors, M. Enell, Discharge of nutrients from Swedish fish farming to adjacent sea areas, Ambio 19 (1) (1990) 28-35.

[132] E. Papatryphon, J. Petit, H. M. G. Van Der Werf, K. J. Sadasivam, K. Claver, Nutrient-balance modeling as a tool for environmental management in aquaculture: the case of trout farming in France, Environmental Management 35 (2) (2005) 161-174. doi:https://doi.org/10.1007/s00267-004-4020-z.

[133] E. Willsteed, A. B. Gill, S. Birchenough, S. R. Jude, Assessing the cumulative environmental effects of marine renewable energy developments: Establishing common ground, Science of the Total Environment 577 (2017) 19-32. doi:https://doi.org/10.1016/j.scitotenv.2016.10.152.

[134] E. A. Willsteed, S. Jude, A. B. Gill, S. N. R. Birchenough, Obligations and aspirations: A critical evaluation of offshore wind farm cumulative impact assessments, Renewable and 
Sustainable Energy Reviews $82 \quad$ (3) (2017) 2332-2345. doi:https://doi.org/10.1016/j.rser.2017.08.079.

[135] TROPOS, Comparative statement/assessment for selected deployment locations including comparison to non-multi-use platforms, Tech. Rep. D6.5, TROPOS Project (2015).

[136] H. Bush, G. Bawn, N. Minns, C. Raimundo, Environmental impact scoping study, Tech. Rep. D9.1, H2OCEAN (2013).

[137] I. Hart, T. Chanvrier, Environmental impact assessment, Tech. Rep. D9.6, H2OCEAN (2015).

[138] A. Nobre, M. Pacheco, R. Jorge, M. F. P. Lopes, L. M. C. Gato, Geo-spatial multi-criteria analysis for wave energy conversion system deployment, Renewable energy 34 (1) (2009) 97-111. doi:https://doi.org/10.1016/j.renene.2008.03.002.

[139] M. J. Punt, R. A. Groeneveld, E. C. Van Ierland, J. H. Stel, Spatial planning of offshore wind farms: A windfall to marine environmental protection?, Ecological Economics 69 (1) (2009) 93-103. doi:https://doi.org/10.1016/j.ecolecon.2009.07.013.

[140] S. Jay, Planners to the rescue: Spatial planning facilitating the development of offshore wind energy, Marine Pollution Bulletin 60 (4) (2010) 493-499. doi:https://doi.org/10.1016/j.marpolbul.2009.11.010.

[141] K. A. Alexander, T. Potts, T. A. Wilding, Marine renewable energy and Scottish west coast fishers: Exploring impacts, opportunities and potential mitigation, Ocean \& Coastal Management 75 (2013) 1-10. doi:https://doi.org/10.1016/j.ocecoaman.2013.01.005.

[142] J. K. Petersen, T. Malm, Offshore windmill farms: threats to or possibilities for the marine environment, AMBIO: A Journal of the Human Environment 35 (2) (2006) 75-80.

[143] P. F. Sale, R. K. Cowen, B. S. Danilowicz, G. P. Jones, J. P. Kritzer, K. C. Lindeman, S. Planes, N. V. C. Polunin, G. R. Russ, Y. J. Sadovy, R. S. Steneck, Critical science gaps impede use of no-take fishery reserves, Trends in Ecology \& Evolution 20 (2) (2005) 74-80. doi:https://doi.org/10.1016/j.tree.2004.11.007.

[144] M. Coll, J. Steenbeek, J. Sole, I. Palomera, V. Christensen, Modelling the cumulative spatial-temporal effects of environmental drivers and fishing in a NW Mediterranean marine ecosystem, Ecological modelling 331 (2016) 100-114. 
doi:https://doi.org/10.1016/j.ecolmodel.2016.03.020.

[145] C. Piroddi, M. Coll, C. Liquete, D. Macias, K. Greer, J. Buszowski, J. Steenbeek, R. Danovaro, V. Christensen, Historical changes of the Mediterranean Sea ecosystem: modelling the role and impact of primary productivity and fisheries changes over time, Scientific reports 7 (2017) 1-18. doi:10.1038/srep44491.

[146] D. Martin, F. Bertasi, M. A. Colangelo, M. de Vries, M. Frost, S. J. Hawkins, E. Macpherson, P. S. Moschella, M. P. Satta, R. C. Thompson, V. U. Ceccherelli, Ecological impact of coastal defence structures on sediment and mobile fauna: evaluating and forecasting consequences of unavoidable modifications of native habitats, Coastal $\begin{array}{lllll}\text { engineering } & 52 & (10-11) & \text { (2005) }\end{array}$ doi:https://doi.org/10.1016/j.coastaleng.2005.09.006.

[147] J. C. Wilson, M. Elliott, The habitat-creation potential of offshore wind farms, Wind Energy 12 (2) (2009) 203-212. doi : https://doi.org/10.1002/we.324.

[148] N. Davis, G. R. VanBlaricom, P. K. Dayton, Man-made structures on marine sediments: Effects on adjacent benthic communities, Marine Biology 70 (3) (1982) 295-303. doi:https://doi.org/10.1007/BF00396848.

[149] F. Barros, A. J. Underwood, M. Lindegarth, The influence of rocky reefs on structure of benthic macrofauna in nearby soft-sediments, Estuarine, Coastal and Shelf Science 52 (2) (2001) 191-199. doi:https://doi.org/10.1006/ecss.2000.0734.

[150] G. Fabi, F. Luccarini, M. Panfili, C. Solustri, A. Spagnolo, Effects of an artificial reef on the surrounding soft-bottom community (central Adriatic Sea), ICES Journal of Marine Science 59 (suppl) (2002)

S343-S349. doi:https://doi.org/10.1006/jmsc.2002.1308.

[151] A. Fukunaga, J. H. Bailey-Brock, Benthic infaunal communities around two artificial reefs in Mamala Bay, Oahu, Hawaii, Marine Environmental Research 65 (3) (2008) 250-263. doi:https://doi.org/10.1016/j.marenvres.2007.11.003.

[152] C. Piroddi, G. Bearzi, V. Christensen, Marine open cage aquaculture in the eastern Mediterranean Sea: a new trophic resource for bottlenose dolphins, Marine Ecology $\begin{array}{lllll}\text { Progress } & \text { Series } & 440 & \text { (2011) 255-266. }\end{array}$ doi:https://doi.org/10.3354/meps09319.

[153] A. Beattie, U. R. Sumaila, V. Christensen, D. Pauly, A model for the bioeconomic 
evaluation of marine protected area size and placement in the North Sea, Natural Resource $\begin{array}{lllll}\text { Modeling } & 15 & \text { (4) } & \text { 413-437. }\end{array}$ doi:https://doi.org/10.1111/j.1939-7445.2002.tb00096.x.

[154] A. K. Salomon, N. P. Waller, C. McIlhagga, R. L. Yung, C. Walters, Modeling the trophic effects of marine protected area zoning policies: A case study, Aquatic Ecology 36 (1) (2002) 85-95. doi : https://doi .org/10.1023/A:1013346622536.

[155] Z. Chen, S. Xu, Y. Qiu, Z. Lin, X. Jia, Modeling the effects of fishery management and marine protected areas on the Beibu Gulf using spatial ecosystem simulation, Fisheries Research $\quad 100$ (2009) $222-229$. doi:https://doi.org/10.1016/j.fishres.2009.08.001.

[156] P. M. Mace, A new role for MSY in single-species and ecosystem approaches to fisheries stock assessment and management, Fish and Fisheries 2 (1) (2001) 2-32. doi:https://doi.org/10.1046/j.1467-2979.2001.00033.x.

[157] D. Pauly, V. Christensen, S. Guénette, T. J. Pitcher, U. R. Sumaila, C. J. Walters, R. Watson, D. Zeller, Towards sustainability in world fisheries, Nature 418 (2002) 689-695. doi:https://doi.org/10.1038/nature01017.

[158] A. D. M. Smith, E. J. Fulton, A. J. Hobday, D. C. Smith, P. Shoulder, Scientific tools to support the practical implementation of ecosystem-based fisheries management, ICES Journal of Marine Science $64 \quad$ (4) (2007) 633-639. doi:https://doi.org/10.1093/icesjms/fsm041.

[159] L. B. Crowder, E. L. Hazen, N. Avissar, R. Bjorkland, C. Latanich, M. B. Ogburn, The impacts of fisheries on marine ecosystems and the transition to ecosystem-based management, Annual Review of Ecology, Evolution, and Systematics 39 (2008) 259-278. doi:10.1146/annurev.ecolsys.39.110707.173406.

[160] M. R. Heithaus, A. Frid, A. J. Wirsing, B. Worm, Predicting ecological consequences of marine top predator declines, Trends in Ecology \& Evolution 23 (4) (2008) 202-210. doi:https://doi.org/10.1016/j.tree.2008.01.003.

[161] K. Hyder, A. G. Rossberg, J. I. Allen, M. C. Austen, R. M. Barciela, H. J. Bannister, P. G. Blackwell, J. L. Blanchard, M. T. Burrows, E. Defriez, T. Dorrington, K. P. Edwards, B. Garcia-Carreras, M. R. Heath, D. J. Hembury, J. J. Heymans, J. Holt, J. E. Houle, S. Jennings, S. Mackinson, S. J. Malcolm, R. McPike, L. Mee, D. K. Mills, C. Montgomery, 
D. Pearson, J. K. Pinnegar, M. Pollicino, E. E. Popova, L. Rae, S. I. Rogers, D. Speirs, M. A. Spence, R. Thorpe, R. K. Turner, J. van der Molen, A. Yool, D. M. Paterson, Making modelling count - increasing the contribution of shelf-seas community and ecosystem models to policy development and management, Marine Policy 61 (2015) 291-302. doi:https://doi.org/10.1016/j.marpol.2015.07.015.

[162] X. Corrales, M. Coll, E. Ofir, C. Piroddi, M. Goren, D. Edelist, J. J. Heymans, J. Steenbeek, V. Christensen, G. Gal, Hindcasting the dynamics of an Eastern Mediterranean marine ecosystem under the impacts of multiple stressors, Marine Ecology Progress Series 580 (2017) 17-36. doi:https://doi.org/10.3354/meps12271.

[163] V. Stelzenmüller, M. Coll, A. D. Mazaris, S. Giakoumi, S. Katsanevakis, M. E. Portman, R. Degen, P. Mackelworth, A. Gimpel, P. G. Albano, V. Almpanidou, J. Claudet, F. Essl, T. Evagelopoulos, J. J. Heymans, T. Genov, S. Kark, F. Micheli, M. G. Pennino, G. Rilov, B. Rumes, J. Steenbeek, H. Ojaveer, A risk-based approach to cumulative effect assessments for marine management, Science of The Total Environment 612 (2018) 1132-1140. doi:https://doi.org/10.1016/j.scitotenv.2017.08.289.

[164] J. W. Baretta, W. Ebenhöh, P. Ruardij, The European regional seas ecosystem model, a complex marine ecosystem model, Netherlands Journal of Sea Research 33 (1995) 233-246. doi:https://doi.org/10.1016/0077-7579(95)90047-0.

[165] E. A. Fulton, N. J. Bax, R. H. Bustamante, J. M. Dambacher, C. Dichmont, P. K. Dunstan, K. R. Hayes, A. J. Hobday, R. Pitcher, É. E. Plagányi, A. E. Punt, M. Savina-Rolland, A. D. M. Smith, D. C. Smith, Modelling marine protected areas: insights and hurdles, Philosophical Transactions of the Royal Society B: Biological Sciences 370 (1681) (2015) 20140278. doi:https://doi.org/10.1098/rstb.2014.0278.

[166] D. Gascuel, M. Coll, C. Fox, S. Guénette, J. Guitton, A. Kenny, L. Knittweis, J. R. Nielsen, G. Piet, T. Raid, M. Travers-Trolet, S. Shephard, Fishing impact and environmental status in European seas: a diagnosis from stock assessments and ecosystem indicators, Fish and Fisheries 17 (1) (2014) 31-55. doi: https://doi .org/10.1111/faf.12090.

[167] T. J. Pitcher, E. A. Buchary, T. Hutton, Forecasting the benefits of no-take human-made reefs using spatial ecosystem simulation, ICES Journal of Marine Science 59 (2002) S17-S26. doi:https://doi.org/10.1006/jmsc.2002.1185.

[168] M. Colléter, D. Gascuel, C. Albouy, P. Francour, L. T. de Morais, A. Valls, F. Le Loc'h, 
Fishing inside or outside? A case studies analysis of potential spillover effect from marine protected areas, using food web models, Journal of Marine Systems 139 (2014) 383-395. doi:https://doi.org/10.1016/j.jmarsys.2014.07.023.

[169] M. Coll, E. Akoglu, F. Arregun-Sánchez, E. A. Fulton, D. Gascuel, J. J. Heymans, S. Libralato, S. Mackinson, I. Palomera, C. Piroddi, L. J. Shannon, J. Steenbeek, S. Villasante, V. Christensen, Modelling dynamic ecosystems: venturing beyond boundaries with the Ecopath approach, Reviews in Fish Biology and Fisheries 25 (2) (2015) 413-424. doi:https://doi.org/10.1007/s11160-015-9386-x.

[170] L. Morissette, K. Kaschner, L. R. Gerber, Ecosystem models clarify the trophic role of whales off Northwest Africa, Marine Ecology Progress Series 404 (2010) 289-302. doi:https://doi.org/10.3354/meps08443.

[171] N. Serpetti, A. R. Baudron, M. T. Burrows, B. L. Payne, P. Helaouet, P. G. Fernandes, J. Heymans, Impact of ocean warming on sustainable fisheries management informs the Ecosystem Approach to Fisheries, Scientific reports 7 (1) (2017) 13438. doi:https://doi.org/10.1038/s41598-017-13220-7.

[172] J. Steenbeek, M. Coll, L. Gurney, F. Mélin, N. Hoepffner, J. Buszowski, V. Christensen, Bridging the gap between ecosystem modeling tools and geographic information systems: Driving a food web model with external spatial-temporal data, Ecological Modelling 263 (2013) 139-151. doi:https://doi.org/10.1016/j.ecolmodel.2013.04.027.

[173] J. Steenbeek, J. Buszowski, V. Christensen, E. Akoglu, K. Aydin, N. Ellis, D. Felinto, J. Guitton, S. Lucey, K. Kearney, S. Mackinson, M. Pan, M. Platts, C. Walters, Ecopath with Ecosim as a model-building toolbox: Source code capabilities, extensions, and variations, Ecological Modelling $\quad 319 \quad$ 178-189. doi:https://doi.org/10.1016/j.ecolmodel.2015.06.031.

[174] L. Tong, Ecopath model-a mass-balance modeling for ecosystem estimation, Marine Fisheries Research 20 (2) (1999) 103-107.

[175] J.-f. Feng, L. Zhu, H.-1. Wang, Study on characters of coastal ecosystem in Bohai Bay with EwE, Marine Environmental Science 29 (6) (2010) 781-784.

[176] Q. Lin, X. S. Jin, B. Zhang, X. Guo, Comparative study on the changes of the Bohai Sea ecosystem structure based on Ecopath model between ten years, Acta Ecologica Sinica 29 
(7) (2009) 3613-3620.

[177] Q. Lin, X.-s. Jin, X.-w. Guo, B. Zhang, Study on the structure and energy flow of the Yangtze River Estuary and adjacent waters ecosystem based on Ecopath model, Journal of Hydroecology 2 (2) (2009) 30-38.

[178] H. Jiang, H.-Q. Cheng, H.-G. Xu, F. Arreguín-Sánchez, M. J. Zetina-Rejón, P. D. M. Luna, W. J. F. Le Quesne, Trophic controls of jellyfish blooms and links with fisheries in the East China Sea, Ecological Modelling $212 \quad$ (3-4) (2008) 492-503. doi:https://doi.org/10.1016/j.ecolmodel.2007.10.048.

[179] J. K. Kaldellis, D. Apostolou, M. Kapsali, E. Kondili, Environmental and social footprint of offshore wind energy. Comparison with onshore counterpart, Renewable Energy 92 (2016) 543-556. doi:https://doi.org/10.1016/j.renene.2016.02.018.

[180] M. Busch, K. Gee, B. Burkhard, M. Lange, N. Stelljes, Conceptualizing the link between marine ecosystem services and human well-being: the case of offshore wind farming, International Journal of Biodiversity Science, Ecosystem Services \& Management 7 (3) (2011) 190-203. doi:https://doi.org/10.1080/21513732.2011.618465.

[181] P. Devine-Wright, Y. Howes, Disruption to place attachment and the protection of restorative environments: A wind energy case study, Journal of Environmental Psychology 30

(2010)

$271-280$.

doi:https://doi.org/10.1016/j.jenvp.2010.01.008.

[182] J. R. Nedwell, S. Cheesman, R. Barham, Measurement of the underwater noise from operational windfarms, and assessment of the potential for effects on the environment, in: The 11th European Conference on Underwater Acoustics, Institute of Acoustics, 2012, pp. 1098-1103.

[183] J. Nedwell, J. Langworthy, D. Howell, Assessment of sub-sea acoustic noise and vibration from offshore wind turbines and its impact on marine wildlife; initial measurements of underwater noise during construction of offshore windfarms, and comparison with background noise, Tech. Rep. 544R0423, COWRIE Ltd (2003).

[184] J. R. Nedwell, S. J. Parvin, B. Edwards, R. Workman, A. G. Brooker, J. E. Kynoch, Measurement and interpretation of underwater noise during construction and operation of offshore windfarms in UK waters, Tech. Rep. 544R0738, COWRIE Ltd (2007).

[185] C. Hattam, T. Hooper, E. Papathanasopoulou, Understanding the Impacts of offshore wind 
farms on well-being, The Crown Estate, 2015.

[186] V. Westerberg, J. B. Jacobsen, R. Lifran, The case for offshore wind farms, artificial reefs and sustainable tourism in the French mediterranean, Tourism Management 34 (2013) 172-183. doi:https://doi.org/10.1016/j.tourman.2012.04.008.

[187] S. Mackinson, H. Curtis, R. Brown, K. McTaggart, N. Taylor, S. Neville, S. Rogers, A report on the perceptions of the fishing industry into the potential socio-economic impacts of offshore wind energy developments on their work patterns and income, Tech. Rep. 133, Centre for Environment Fisheries and Aquaculture Science (2006).

[188] J. Firestone, W. Kempton, Public opinion about large offshore wind power: Underlying factors, Energy policy $35 \quad$ (3) (2007) 1584-1598. doi:https://doi.org/10.1016/j.enpol.2006.04.010.

[189] A. Vanhulle, R. Houthave, M. Di Marcantonio, Seascape and socio-economic study: final results, Offshore wind farms in the Belgian part of the North Sea: Early environmental impact assessment and spatio-temporal variability. Royal Belgian Institute of Natural Sciences. Management Unit of the North Sea Mathematical Models. Marine Ecosystem Management Unit: Brussel (2010) 165-186.

[190] A. Waldo, Offshore wind power in Sweden - A qualitative analysis of attitudes with particular focus on opponents, Energy Policy $41 \quad$ (2012) 692-702. doi:https://doi.org/10.1016/j.enpol.2011.11.033.

[191] I. Bailey, J. West, I. Whitehead, Out of sight but not out of mind? Public perceptions of wave energy, Journal of Environmental Policy \& Planning 13 (2) (2011) 139-157. doi:https://doi.org/10.1080/1523908x.2011.573632.

[192] C. Haggett, Over the sea and far away? A consideration of the planning, politics and public perception of offshore wind farms, Journal of Environmental Policy \& Planning 10 (3) (2008) 289-306. doi:https://doi .org/10 .1080/15239080802242787.

[193] WAVEPLAM, Wave Energy: A Guide for Investors and Policy Makers (accessed May 9 , 2018).

URL

http://www.waveplam.eu/files/downloads/D.3.2.Guidelienes_FI NAL . pdf.

[194] S. Kerr, L. Watts, J. Colton, F. Conway, A. Hull, K. Johnson, S. Jude, A. Kannen, S. 
MacDougall, C. McLachlan, T. Potts, J. Vergunst, Establishing an agenda for social studies research in marine renewable energy, Energy Policy 67 (2014) 694-702. doi:https://doi.org/10.1016/j.enpol.2013.11.063.

[195] A. Babarit, D. Bull, K. Dykes, R. Malins, K. Nielsen, R. Costello, J. Roberts, C. B. Ferreira, B. Kennedy, J. Weber, Stakeholder requirements for commercially successful wave energy converter farms, Renewable Energy 113 (2017) 742-755. doi:https://doi.org/10.1016/j.renene.2017.06.040.

[196] F. Flocard, D. Ierodiaconou, I. R. Coghlan, Multi-criteria evaluation of wave energy projects on the south-east Australian coast, Renewable Energy 99 (2016) 80-94. doi:https://doi.org/10.1016/j.renene.2016.06.036.

[197] S. Kerr, J. Colton, K. Johnson, G. Wright, Rights and ownership in sea country: implications of marine renewable energy for indigenous and local communities, Marine $\begin{array}{llll}\text { Policy } & 52 & \text { (2015) }\end{array}$ doi:https://doi.org/10.1016/j.marpol.2014.11.002.

[198] S. Kerr, K. Johnson, J. Colton, G. Wright, S. Weir, Mare reservarum: enclosure of the commons and the evolution of marine rights in an era of ocean industrialisation, in: G. Wright, S. Kerr, K. Johnson (Eds.), Ocean Energy: Governance Challenges for Wave and Tidal Stream Technologies, Routledge, United Kingdom, 2018, pp. 80-98.

[199] S. Vezmar, A. Spajić, D. Topić, D. Šljivac, L. Jozsa, Positive and negative impacts of renewable energy sources, International Journal of Electrical and Computer Engineering Systems 5 (2) (2014) 15-23.

[200] T. Potts, D. Burdon, E. Jackson, J. Atkins, J. Saunders, E. Hastings, O. Langmead, Do marine protected areas deliver flows of ecosystem services to support human welfare?, Marine Policy $44 \quad$ (2014) 139-148. doi:https://doi.org/10.1016/j.marpol.2013.08.011.

[201] R. Bedard, Economic and social benefits from wave energy conversion marine technology, Marine Technology Society Journal 41 (3) (2007) 44-50. doi:https://doi.org/10.4031/002533207787442123.

[202] C. McLachlan, You don't do a chemistry experiment in your best china: Symbolic interpretations of place and technology in a wave energy case, Energy Policy 37 (12) (2009) 
doi:https://doi.org/10.1016/j.enpol.2009.07.057.

[203] K. A. Alexander, T. A. Wilding, J. J. Heymans, Attitudes of Scottish fishers towards marine renewable energy, Marine Policy 37 (2013) 239-244. doi:https://doi.org/10.1016/j.marpol.2012.05.005.

[204] S. Kerr, S. Weir, Community benefits schemes: Fair shares or token gestures?, in: G. Wright, S. Kerr, K. Johnson (Eds.), Ocean Energy: Governance Challenges for Wave and Tidal Stream Technologies, Routledge, United Kingdom, 2018, pp. 191-204.

[205] G. Krause, E. Mikkelsen, The socio-economic dimensions of offshore aquaculture in a multi-use setting, in: Aquaculture Perspective of Multi-Use Sites in the Open Ocean, Springer, 2017, pp. 163-186. doi:https://doi.org/10.1007/978-3-319-51159-7_8.

[206] B. A. Costa-Pierce, Sustainable ecological aquaculture systems: The need for a new social contract for aquaculture development, Marine Technology Society Journal 44 (3) (2010) 88-112. doi:https://doi.org/10.4031/MTSJ.44.3.3.

[207] G. Krause, C. Brugere, A. Diedrich, M. W. Ebeling, S. C. A. Ferse, E. Mikkelsen, J. A. P. Agúndez, S. M. Stead, N. Stybel, M. Troell, A revolution without people? Closing the people-policy gap in aquaculture development, Aquaculture 447 (2015) 44-55. doi:https://doi.org/10.1016/j.aquaculture.2015.02.009.

[208] O. J. Bergfjord, Risk perception and risk management in Norwegian aquaculture, Journal of Risk Research $12 \quad$ (1) (2009) 91-104. doi:https://doi.org/10.1080/13669870802488941.

[209] B. Belton, D. C. Little, L. X. Sinh, The social relations of catfish production in Vietnam, Geoforum 42 (5) (2011) 567-577.

[210] B. Belton, M. M. Haque, D. C. Little, L. X. Sinh, Certifying catfish in Vietnam and Bangladesh: Who will make the grade and will it matter?, Food Policy 36 (2) (2011) 289-299. doi:https://doi.org/10.1016/j.foodpol.2010.11.027.

[211] B. Aarset, S. Beckmann, E. Bigne, M. Beveridge, T. Bjorndal, J. Bunting, P. McDonagh, C. Mariojouls, J. Muir, A. Prothero, R. Lucia, A. Smith, R. Tveteras, J. Young, The European consumers' understanding and perceptions of the "organic" food regime: The case of aquaculture, British Food Journal 106 (2) (2004) 93-105. doi:https://doi.org/10.1108/00070700410516784. 
[212] C. Pattanaik, S. N. Prasad, Assessment of aquaculture impact on mangroves of Mahanadi delta (Orissa), East coast of India using remote sensing and GIS, Ocean \& Coastal $\begin{array}{lllll}\text { Management } & 54 & \text { (11) } & \text { (2011) 789-795. }\end{array}$ doi:https://doi.org/10.1016/j.ocecoaman.2011.07.013.

[213] M. D. Smith, C. A. Roheim, L. B. Crowder, B. S. Halpern, M. Turnipseed, J. L. Anderson, F. Asche, L. Bourillon, A. G. Guttormsen, A. Khan, L. A. Liguori, A. McNevin, M. I. O’Connor, D. Squires, P. Tyedmers, C. Brownstein, K. Carden, D. H. Klinger, R. Sagarin, K. A. Selkoe, Sustainability and global seafood, Science 327 (2010) 784-786. doi:10.1126/science.1185345.

[214] D. Pauly, The Sea Around Us Project: documenting and communicating global fisheries impacts on marine ecosystems, AMBIO: a Journal of the Human Environment 36 (4) (2007) 290-295. doi:https://doi.org/10.1579/0044-7447(2007)36 [290:TSAUPD] 2. $0 . \mathrm{CO} ; 2$.

[215] C. Pipitone, F. Badalamenti, T. V. Fernández, G. D’Anna, Spatial management of fisheries in the Mediterranean sea: Problematic issues and a few success stories, in: Advances in Marine Biology, Vol. 69, Elsevier, 2014, pp. 371-402. doi:https://doi.org/10.1016/B978-0-12-800214-8.00010-4.

[216] R. Tiller, R. Gentry, R. Richards, Stakeholder driven future scenarios as an element of interdisciplinary management tools; the case of future offshore aquaculture development and the potential effects on fishermen in Santa Barbara, California, Ocean \& Coastal Management 73 (2013)

$127-135$. doi:https://doi.org/10.1016/j.ocecoaman.2012.12.011.

[217] D. Peel, M. Lloyd, Governance and planning policy in the marine environment: regulating aquaculture in Scotland, The Geographical Journal 174 (4) (2008) 361-373.

[218] J. Klijnstra, X. Zhang, S. van der Putten, C. Röckmann, Technical risks of offshore structures, in: Aquaculture Perspective of Multi-Use Sites in the Open Ocean, Springer, 2017,

pp. $115-127$. doi:https://doi.org/10.1007/978-3-319-51159-7_5.

[219] S. Jude, A. B. Gill, C. Mauelshagen, E. Willsteed, Risk and ocean energy, in: G. Wright, S. Kerr, K. Johnson (Eds.), Ocean Energy: Governance Challenges for Wave and Tidal 
Stream Technologies, Routledge, United Kingdom, 2018, pp. 13-26.

[220] G. Wright, A. M. O’Hagan, J. de Groot, Y. Leroy, N. Soininen, R. Salcido, M. A. Castelos, S. Jude, J. Rochette, S. Kerr, Establishing a legal research agenda for ocean energy, Marine $\begin{array}{llll}\text { Policy } & 63 & \text { (2016) }\end{array}$ doi:https://doi.org/10.1016/j.marpol.2015.09.030.

[221] A. Brito-Melo, J. Huckerby (Eds.), 2012 Annual Report, The Executive Committee of Ocean Energy Systems, 2012.

[222] A. Brito-Melo, J. L. Villate (Eds.), 2015 Annual Report, The Executive Committee of Ocean Energy Systems, 2015.

[223] M. Arshad, B. C. O'Kelly, Offshore wind-turbine structures: a review, Proceedings of the Institution of Civil Engineers-Energy 166 (4) (2013) 139-152. doi:https://doi.org/10.1680/ener.12.00019.

[224] M. Collu, M. Borg, Design of floating offshore wind turbines, in: Offshore Wind Farms, Elsevier, 2016, pp. 359-385. doi:https://doi.org/10.1016/B978-0-08-100779-2.00011-8.

[225] M. Karimirad, Offshore Energy Structures: for Wind power, wave energy and hybrid marine platforms, Springer, 2014.

[226] H. M. Jansen, S. Van Den Burg, B. Bolman, R. G. Jak, P. Kamermans, M. Poelman, M. Stuiver, The feasibility of offshore aquaculture and its potential for multi-use in the North Sea, Aquaculture International 24 (3) (2016) 735-756. doi:https://doi.org/10.1007/s10499-016-9987-y.

[227] H. Osawa, T. Miyazaki, Wave-PV hybrid generation system carried in the offshore floating type wave power device Mighty Whale, in: OCEANS'04. MTTS/IEEE TECHNO-OCEAN'04, Vol. 4, IEEE, 2004, pp. 1860-1866. doi:10.1109/OCEANS.2004.1406427.

[228] G. Barlowe, R. Day, D. Kilfoyle, R. Roberts, G. Smith, Hybrid renewable energy systems for off-shore naval installations, in: Photovoltaic Specialists Conference, 1988., Conference Record of the Twentieth IEEE, IEEE, 1988, pp. 1179-1181.

[229] A. Uihlein, D. Magagna, Wave and tidal current energy-A review of the current state of research beyond technology, Renewable and Sustainable Energy Reviews 58 (2016) 1070-1081.doi:https://doi.org/10.1016/j.rser.2015.12.284. 
[230] Y. Shirai, S. Minamoto, K. Yonemura, M. L. Rahman, Output power control of hybrid off-shore-wind and tidal turbine generation system with battery storage system, in: 19th International Conference on Electrical Machines and Systems (ICEMS), IEEE, 2016, pp. $1-6$.

[231] R. Hilborn, F. Micheli, G. A. De Leo, Integrating marine protected areas with catch regulation, Canadian Journal of Fisheries and Aquatic Sciences 63 (3) (2006) 642-649. doi:https://doi.org/10.1139/f05-243.

[232] D. Alston, A. Cabarcas, J. Capella, D. Benetti, S. Keene-Meltzoff, J. Bonilla, R. Cortes, Environmental and social impacts of sustainable offshore cage culture production in Puerto Rican waters, Tech. Rep. NA16RG1611, NOAA (2005).

[233] R. Pittenger, B. Anderson, D. D. Benetti, P. Dayton, B. Dewey, R. Goldburg, A. Rieser, B. Sher, A. Sturgulewski, Sustainable marine aquaculture: fulfilling the promise. managing the risks, Tech. rep., The Pew Charitable Trusts (2007).

[234] R. R. Gentry, S. E. Lester, C. V. Kappel, C. White, T. W. Bell, J. Stevens, S. D. Gaines, Offshore aquaculture: Spatial planning principles for sustainable development, Ecology $\begin{array}{llllll}\text { and } & \text { evolution } & 7 & \text { (2) } & \text { (2017) }\end{array}$ doi:https://doi.org/10.1002/ece3.2637.

[235] S. E. Shumway, Shellfish aquaculture and the environment, John Wiley \& Sons, 2011. doi:10.1002/9780470960967.

[236] C. W. McKindsey, P. Archambault, M. D. Callier, F. Olivier, Influence of suspended and off-bottom mussel culture on the sea bottom and benthic habitats: a review, Canadian $\begin{array}{llllll}\text { Journal } & \text { of } & \text { Zoology } & 89 & \text { (7) }\end{array}$ doi:https://doi.org/10.1139/z11-037.

[237] C. Röckmann, S. Lagerveld, J. Stavenuiter, Operation and maintenance costs of offshore wind farms and potential multi-use platforms in the Dutch North Sea, in: Aquaculture Perspective of Multi-Use Sites in the Open Ocean, Springer, 2017, pp. 97-113. doi:https://doi.org/10.1007/978-3-319-51159-7_4.

[238] State Oceanic Administration People's Republic of China, 13th Ocean Energy Development Five Year Plan (2016-2020) (accessed February 28, 2018).

URL http://www.soa.gov.cn/zwgk/zcgh/kxcg/201701/t20170112_54473 
. html

[239] European Commission, Blue growth. opportunities for marine and maritime sustainable growth, Communication from the Commission to the European Parliament, the Council, the European Economic and Social Committee and the Committee of the Regions (2012).

[240] Horizon 2020, Work Programme 2014-2015 -General Annexes (accessed April 28, 2018). URL

http://ec.europa.eu/research/horizon2020/pdf/work-programme s/general_annexes_draft_work_programme.pdf

[241] M. Menicou, V. Vassiliou, Prospective energy needs in Mediterranean offshore aquaculture: Renewable and sustainable energy solutions, Renewable and Sustainable $\begin{array}{llllll}\text { Energy } & \text { Reviews } & 14 & (9) & \text { 3084-3091. }\end{array}$ doi:https://doi.org/10.1016/j.rser.2010.06.013. 


\section{Declaration of interests}

$\bigotimes$ The authors declare that they have no known competing financial interests or personal relationships that could have appeared to influence the work reported in this paper.

$\square$ The authors declare the following financial interests/personal relationships which may be considered as potential competing interests: 